\title{
Dynamics of Somatostatin Type 2A Receptor Cargoes in Living Hippocampal Neurons
}

\author{
Benjamin Lelouvier, ${ }^{1,2}$ Gianluca Tamagno, ${ }^{3,4}$ Angela M. Kaindl, ${ }^{1,2}$ Alexandre Roland, ${ }^{5}$ Vincent Lelievre,, 2 \\ Virginia Le Verche, ${ }^{1,2}$ Catherine Loudes, ${ }^{3,4}$ Pierre Gressens, ${ }^{1,2}$ Annie Faivre-Baumann, ${ }^{3,4}$ Zsolt Lenkei, ${ }^{5}$ and \\ Pascal Dournaud ${ }^{1,2}$ \\ ${ }^{1}$ Institut National de la Santé et de la Recherche Médicale (INSERM), Unité 676, 75019 Paris, France, 2Université Denis Diderot-Paris 7, 75018 Paris, \\ France, ${ }^{3}$ INSERM, Unité 549, 75014 Paris, France, ${ }^{4}$ Université René Descartes-Paris 5, 75006 Paris, France, and ${ }^{5}$ Ecole Supérieure de Physique et de Chimie \\ Industrielles-Unité Mixte de Recherche Centre National de la Recherche Scientifique 7637, 75005 Paris, France
}

Despite the large number of G-protein-coupled receptor (GPCR) types expressed in the CNS, little is known about their dynamics in neuronal cells. Dynamic properties of the somatostatin type $2 \mathrm{~A}$ receptor were therefore examined in resting conditions and after agonist activation in living hippocampal neurons. Using fluorescence recovery after photobleaching experiments, we found that, in absence of ligand, the $s s t_{2 \mathrm{~A}}$ receptor is mobile and laterally and rapidly diffuse in neuronal membranes. We then observed by live-cell imaging that, after agonist activation, membrane-associated receptors induce the recruitment of $\beta$-arrestin 1-enhanced green fluorescent protein (EGFP) and $\beta$-arrestin 2-EGFP to the plasma membrane. In addition, $\beta$-arrestin 1-EGFP translocate to the nucleus, suggesting that this protein could serve as a nuclear messenger for the $s_{2} t_{2 \mathrm{~A}}$ receptor in neurons. Receptors are then recruited to preexisting clathrin coated pits, form clusters that internalize, fuse, and move to a perinuclear compartment that we identified as the trans-Golgi network (TGN), and recycle. Receptor cargoes are transported through a microtubule-dependent process directly from early endosomes/recycling endosomes to the TGN, bypassing the late endosomal compartment. Together, these results provide a comprehensive description of GPCR trafficking in living neurons and provide compelling evidence that GPCR cargoes can recycle through the TGN after endocytosis, a phenomenon that has not been anticipated from studies of non-neuronal cells.

Key words: $\beta$-arrestin; clathrin; endocytosis; FRAP; trans-Golgi network; somatostatin receptor

\section{Introduction}

G-protein-coupled receptors (GPCRs) belong to the largest family of cell surface molecules involved in signal transduction and mediate numerous physiological functions of peptide and nonpeptide neurotransmitters (Pierce et al., 2002). Agoniststimulated GPCRs first trigger the activation of heterotrimeric G-proteins that modulate the generation of diffusible second messengers and entry of ions at the plasma membrane. Recent evidence suggests a second signaling mechanism that involves a family of adaptor molecules, the $\beta$-arrestins (Ferguson, 2001; Gainetdinov et al., 2004). These proteins promote the internalization and desensitization of several GPCRs through the recruitment of key endocytic proteins (Premont and Gainetdinov, 2007). Receptor-bound $\beta$-arrestins can also activate nonreceptor tyrosine kinases and mitogen-activated protein kinases, which, in turn, trigger a large variety of physiological responses (Shenoy

\footnotetext{
Received Sept. 25, 2007; revised Feb. 18, 2008; accepted Feb. 18, 2008.

This work was supported by Institut National de la Santé et de la Recherche Médicale. A.R. was supported by Fondation pour la Recherche Médicale. We thank Lone Helboe for providing the antiserum against the somatostatin $\mathrm{sst}_{2 \mathrm{~A}}$ receptor. We also thank Zsolt Csaba for critical reading of this manuscript and Jacques Epelbaum for comments during the project.

Correspondence should be addressed to Dr. Pascal Dournaud, Institut National de la Santé et de la Recherche Médicale Unité 676, Hôpital Robert Debré, 48 Boulevard Sérurier, 75019 Paris, France. E-mail: pascal.dournaud@inserm.fr.

DOI:10.1523/JNEUROSCI.4379-07.2008

Copyright $\odot 2008$ Society for Neuroscience $\quad$ 0270-6474/08/284336-14\$15.00/0
}

and Lefkowitz, 2005; DeWire et al., 2007). In addition, some GPCRs can induce the translocation of $\beta$-arrestin 1 to the nucleus, an event involved in the regulation of histone acetylation and gene transcription (Kang et al., 2005; DeWire et al., 2007). After endocytosis, ligand-activated receptors are typically recycled to the cell surface to promote functional resensitization, or directed to lysosomes leading to proteolytic receptor downregulation (Tsao and von Zastrow, 2000; Tsao et al., 2001; Wolfe and Trejo, 2007). Ligand-promoted translocation of a given receptor protein from the plasma membrane into the cell interior thus represents a key cellular pathway of GPCR signaling.

Molecular mechanisms underlying GPCR endocytosis and postendocytosis are receptor specific, may vary between cell types, and are still not clearly characterized. Surprisingly, in neurons, although recent promising approaches are emerging (Scherrer et al., 2006; Yudowski et al., 2006), analysis of GPCR trafficking has been mainly limited to antibody labeling. In particular, receptor mobility at the plasma membrane as well as formation, maturation, and sorting of GPCR cargo over time remain incompletely characterized in living neurons. In this study, we first examined the mobility of the somatostatin (SRIF) type 2A $\left(\mathrm{sst}_{2 \mathrm{~A}}\right)$ receptor at the plasma membrane of cultured hippocampal neurons by fluorescence recovery after photobleaching (FRAP). Live-cell confocal imaging was then used to visualize early and late trafficking events of this receptor after agonist ac- 
A- sst2A-WT

D-

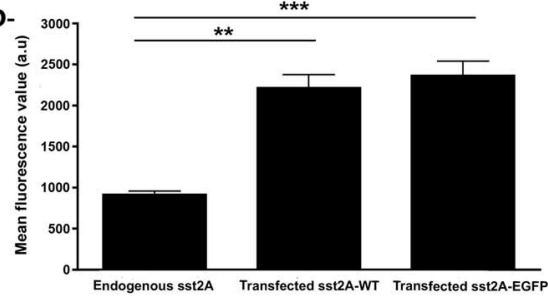

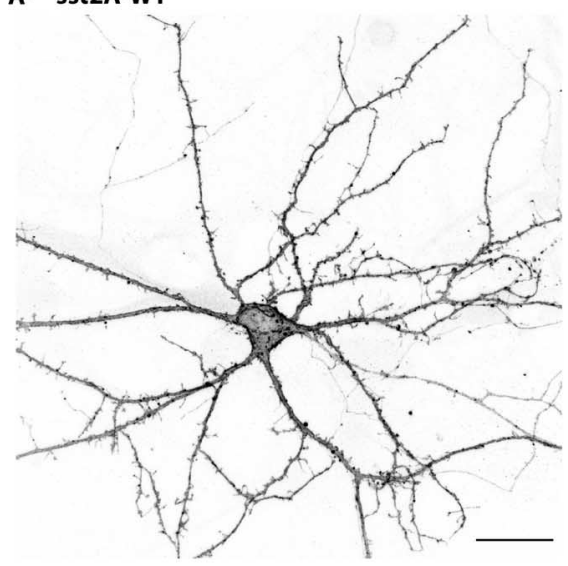

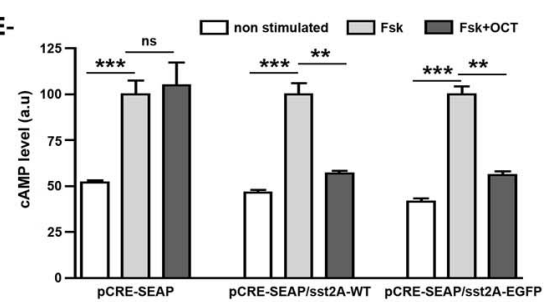

B-sst2A-EGFP

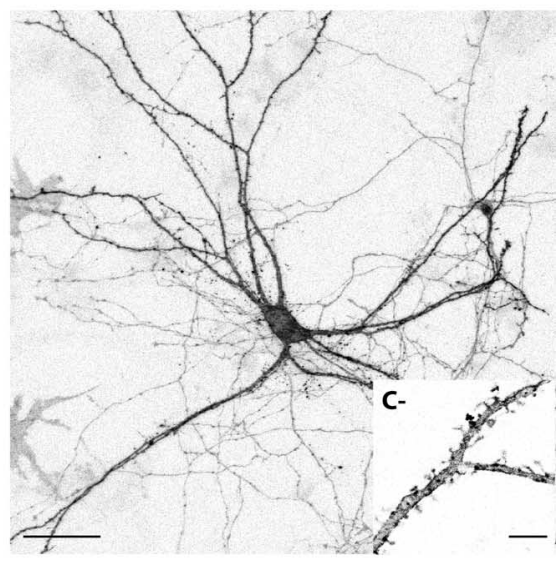

F-

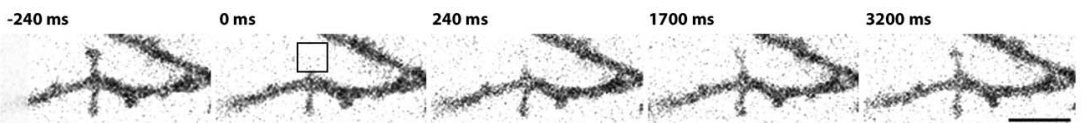

G-
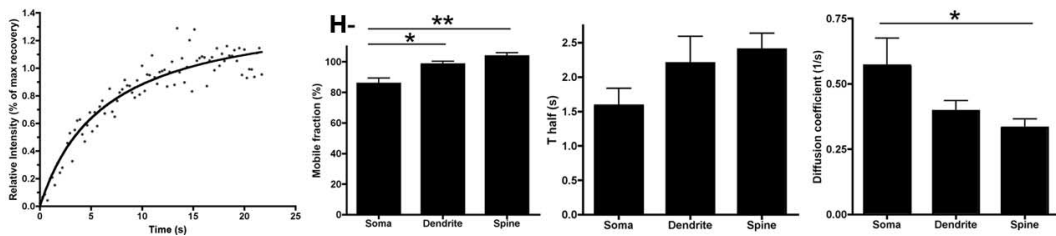

Figure 1. Characterization of transfected $\mathrm{sst}_{2 \mathrm{~A}}$ receptors in hippocampal neurons. $\boldsymbol{A}$, Hippocampal neurons were transfected with a plasmid encoding the wild-type receptor ( $\left.s s_{2 A}-\mathrm{WT}\right)$, fixed, and processed for fluorescence immunocytochemistry for visualization of the receptor by confocal microscopy. Note the intense $s \mathrm{St}_{2 \mathrm{~A}}$-WT fluorescence localized at the membrane of the soma and the dendrites of this transfected neuron. $\mathrm{sst}_{2 \mathrm{~A}}$-WT fluorescence is also visible in spine heads. Scale bar, $25 \mu \mathrm{m}$. B, C, Hippocampal neurons were transfected with a plasmid encoding the sst ${ }_{2 A}$ receptor tagged with EGFP (sst $2 A-E G F P$ ) and processed for live-cell confocal microscopy. As observed for the wild-type receptor, the $s_{2}{ }_{2 A}-E G F P$ is enriched at the somatodendritic membrane domain as well as in spine heads. Scale bars: $\boldsymbol{B}, 50 \mu \mathrm{m} ; \boldsymbol{C}, 5 \mu \mathrm{m}$. D, Expression of endogenous and transfected sst ${ }_{2 A}$ receptors as measured by immunocytochemistry and confocal microscopy. The bar charts represent mean fluorescence measured at the membrane of neurons expressing the endogenous receptor or expressing the sst ${ }_{2 \mathrm{~A}}$-WT or the sst $2 \mathrm{~A}$-EGFP receptor ( $n=10$; mean \pm SEM; ${ }^{* *} p<0.001$; a.u., arbitrary unit). $\boldsymbol{E}$, CHO cells were transfected with $\mathrm{pCRE-SEAP}$ alone or cotransfected with pCRE-SEAP and either the $s s_{2 A}-$ WT or $s s t_{2 A}$-EGFP receptor. OCT induces a significant decrease in the level of cAMP in CHO cells stimulated by forskolin (Fsk) and expressing the $s \mathrm{St}_{2 \mathrm{~A}}-\mathrm{WT}$ or $s \mathrm{Ct}_{2 \mathrm{~A}}$-EGFP receptor. This effect was not observed in cells expressing pCRE-SEAP alone ( $n=6$; mean \pm SEM; ${ }^{* *} p<0.001,{ }^{* *} p<0.0001$; ns, nonsignificant; a.u., arbitrary unit). $\boldsymbol{F}$, Representative time series from a FRAP experiment in spine heads. Bleaching of $s_{2} t_{2 A}$-EGFP (delimited by black borders) is followed by rapid recovery of fluorescence. Scale bar, $2 \mu \mathrm{m}$. G, Graph shows normalized FRAP curve from bleached area shown in $\boldsymbol{F}$. $\boldsymbol{H}$, Averaged mobile fractions, half-time of recoveries ( $T$ half), and diffusion coefficients for somatic membrane, dendritic membrane, and spine heads $\left(n=15\right.$; mean \pm SEM; $\left.{ }^{*} p<0.05,{ }^{* *} p<0.001\right)$.

tivation. Real-time trafficking of the $\mathrm{sst}_{2 \mathrm{~A}}$ receptor was also examined in regard to key proteins of the endocytic pathway, clathrin and $\beta$-arrestins 1 and 2 . The sst $_{2 \mathrm{~A}}$ receptor is the major subtype of the somatostatin receptor family in the CNS (Dournaud et al., 2000; Csaba and Dournaud, 2001) and mediates SRIF inhibitory actions (Vezzani and Hoyer, 1999; Peineau et al., 2003; Bassant et al., 2005). Several studies have linked sst2 receptor signaling to the etiology of various CNS disorders including epilepsy (Vezzani and Hoyer, 1999; Csaba et al., 2004, 2005), ischemia (Stumm et al., 2004; Mastrodimou et al., 2005), and Alzhei- mer's disease (Saito et al., 2005). The sst ${ }_{2 \mathrm{~A}}$ receptor rapidly internalizes in the $\mathrm{CNS}$ after activation by either endogenous or exogenous ligands (Dournaud et al., 1998; Csaba et al., 2001, 2007; Stumm et al., 2004), and therefore represents an interesting receptor model for dynamic studies in living neurons.

\section{Materials and Methods}

DNA constructs. pcDNA3 plasmid construct of the wild-type mouse sst $_{2 \mathrm{~A}}$ cDNA $(98.1 \%$ identity with rat $\left.s t_{2 \mathrm{~A}}\right)$, designated $\mathrm{sst}_{2 \mathrm{~A}}-\mathrm{WT}$, were modified by directed mutagenesis (QuikChange Site-Directed Mutagenesis kit; Stratagene, La Jolla, CA) and excision/ligation experiment to obtain the C-terminal labeled versions of the receptor: sst $_{2 \mathrm{~A}}-\mathrm{pEGFP-N1}\left[\mathrm{sst}_{2 \mathrm{~A}}\right.$-enhanced green fluorescent protein (EGFP)] and $\mathrm{sst}_{2 \mathrm{~A}^{-}}$ mCherry-N1 (sst $2 \mathrm{~A}$-mCherry) derived from pEGFP-N1 plasmid (Clontech, Mountain View, CA).

The pCRE-secreted alkaline phosphatase (SEAP), EGFP $\beta$-arrestin 1 and 2 , and Ds-Red clathrin plasmids were kindly provided by Dr. Lakshmi A. Devi (Mount Sinai School of Medicine, New York, NY), Dr. Stefan Schulz (Ottovon-Guericke-Universität, Magdeburg, Germany), and Dr. Tomas Kirchhausen (Harvard University, Boston, MA), respectively. Amplification and extraction of plasmids were performed with $\mathrm{DH} 5 \alpha$ and One Shot TOP 10 Chemically Competent Escherichia coli (Invitrogen, Carlsbad, CA) and Qiagen (Hilden, Germany) kit.

Cell cultures and transfections. Hippocampi were dissected from 18-d-old embryo Sprague Dawley rat brains and dissociated in HBSS with $0.25 \%$ trypsin and $0.1 \%$ DNase 1 . Hippocampal neurons were plated on glass coverslips previously coated with gelatin and poly-L-lysine. Neurons were grown in Neurobasal medium (Invitrogen) supplemented with B27 and glutamine (Invitrogen) and maintained in an incubator at $5 \% \mathrm{CO}_{2}$.

Hippocampal neurons were transfected at day in vitro (DIV) 3 with the appropriate cDNA (wild-type sst ${ }_{2 \mathrm{~A}}$ receptor, EGFP-tagged $\mathrm{sst}_{2 \mathrm{~A}}$ receptor, mCherry-tagged $\mathrm{sst}_{2 \mathrm{~A}}$ receptor, EGFPtagged $\beta$-arrestin 1, EGFP-tagged $\beta$-arrestin 2 , or Ds-Red-tagged clathrin) using Lipofectamine 2000 (Invitrogen) in OptiMEM medium (Invitrogen). AraC (cytosine $\beta$-D-arabinofuranoside; Sigma, St. Louis, MO), polyunsaturated fatty acids (cis-4,7,10,13,16,19docosahexaenoic acid, arachidonic acid; Sigma), and antibiotics (penicillin streptomycin; Invitrogen) were added at DIV 4. All experiments were realized $8-12 \mathrm{~d}$ after transfection.

Pharmacological treatments. For real-time experiments, the imaging chamber was perfused 1-20 min with either $1 \mu \mathrm{M}$ SRIF-14 (Peninsula Laboratories, San Carlos, CA) or $1 \mu \mathrm{M}$ of the $\mathrm{sst}_{2 \mathrm{~A}}$ receptor agonist octreotide (OCT) (SMS 201-995; kindly provided by Dr. Daniel Hoyer, Novartis Pharma, Basel, Switzerland) diluted in the isotonic medium. In some experiments, neurons were perfused with $10 \mu \mathrm{M}$ of the $s_{2 \mathrm{~A}}$ receptor antagonist BIM-23627 (kindly provided by Dr. Michael Culler, Biomeasure, Milford, MA) with or without $1 \mu \mathrm{M}$ SRIF-14 or OCT.

For time course experiments, neurons were incubated with $1 \mu \mathrm{M}$ OCT 
(SMS 201-995; sst $_{2 \mathrm{~A}}$ receptor agonist) in Neurobasal medium for 1-20 min and fixed immediately or after rinsing and preincubation for appropriate times of recovery in Neurobasal medium. In some experiments, neurons were incubated with $10 \mu \mathrm{M}$ of the $s_{2} t_{2 \mathrm{~A}}$ receptor antagonist BIM-23627 with or without $1 \mu \mathrm{M}$ SRIF-14 or OCT.

To block $\mathrm{G}_{\mathrm{i} / \mathrm{o}}$-mediated signal transduction or inhibit the G-protein-coupled receptor kinase 2 (GRK2), hippocampal neurons were respectively treated with pertussis toxin (PTX) $(100 \mathrm{ng} / \mathrm{ml}$; Sigma) for $20 \mathrm{~h}$ or with suramin (3 $\mu \mathrm{M}$; Sigma) for $30 \mathrm{~min}$ in Neurobasal medium at $37^{\circ} \mathrm{C}$ before addition of OCT.

To depolymerize microtubules or inhibit protein synthesis, hippocampal neurons were treated with colchicine ( $25 \mu \mathrm{M}$; Sigma) for $1 \mathrm{~h}$ or with cycloheximide (100 $\mu \mathrm{M}$; Sigma) for $30 \mathrm{~min}$ in Neurobasal medium, respectively, at $37^{\circ} \mathrm{C}$ before addition of OCT.

Immunocytochemistry. Neurons were fixed with $4 \%$ paraformaldehyde supplemented with $4 \%$ sucrose for $20 \mathrm{~min}$ at room temperature. The cells were washed in PBS and incubated 30 min with 5\% normal donkey serum (Sigma). Primary antibodies were diluted in PBS with $1 \%$ normal donkey serum and $0.1 \%$ saponine or Triton X-100 and incubated overnight at $4^{\circ} \mathrm{C}$. Neurons were washed in PBS and subsequently incubated with secondary antibodies diluted in PBS with $1 \%$ normal donkey serum and $0.1 \%$ saponine or Triton X-100 for $1 \mathrm{~h}$ at room temperature. Finally, cells were washed in PBS and mounted with Fluoromount (Southern Biotech, Birmingham, AL).

Antibodies. Endogenous and transfected sst $_{2 \mathrm{~A}}$ receptor was immunolocalized using a fully characterized antiserum raised in rabbit against the C-terminal segment 330-369 of the human protein $(1 / 20,000)$ (Bassant et al., 2005; Csaba et al., 2007). Mouse monoclonal antibodies were used to detect MAP2 (microtubule-associated protein 2) (MAB378; 1:10,000; Millipore Bioscience Research Reagents, Temecula, CA), transferrin receptor (TfR) (13-6800; 1:10,000; Zymed Laboratories, South San Francisco, CA), early endosome antigen 1 (EEA1) (610457; 1:100; BD Transduction Laboratories, Lexington, KY), syntaxin 6 (S55420; 1:5000; BD Transduction Laboratories), clathrin heavy chain (610499; 1:500; BD Transduction Laboratories), the trans-Golgi network specific integral membrane protein (TGN38) (MA3-063; 1:800; Affinity Bioreagents, Golden, CO), protein disulfide isomerase (PDI) (MA3-019; 1:1000; Affinity Bioreagents), Golgi matrix protein of 130 $\mathrm{kDa}$ (GM130) (610822; 1:200; BD Transduction Laboratories), and lysosome-associated membrane protein 1 (LAMP-1) (VAM-EN001; 1:100; Nventa Biopharmaceuticals, San Diego, CA).

Secondary antibodies used were cyanine 3 (Cy3)-conjugated donkey anti-rabbit and Cy3-conjugated donkey anti-mouse (Jackson ImmunoResearch, West Grove, PA), Alexa Fluor 488 (A488)-conjugated donkey anti-rabbit and A488-conjugated donkey anti-mouse (Invitrogen).

cAMP accumulation assay. A highly sensitive gene reporter assay using SEAP was used to measure intracellular cAMP after sst ${ }_{2 \mathrm{~A}}$ receptor agonist treatment of $\mathrm{CHO}$ cells transfected with the wild-type $\mathrm{sst}_{2 \mathrm{~A}}$ receptor or the EGFP-tagged sst $_{2 \mathrm{~A}}$ receptor. This cell line was chosen because it does not express endogenous somatostatin receptors. The construct used (pCRE-SEAP) presents four cAMP-responsive elements (CRE), upthe drastic and opposite
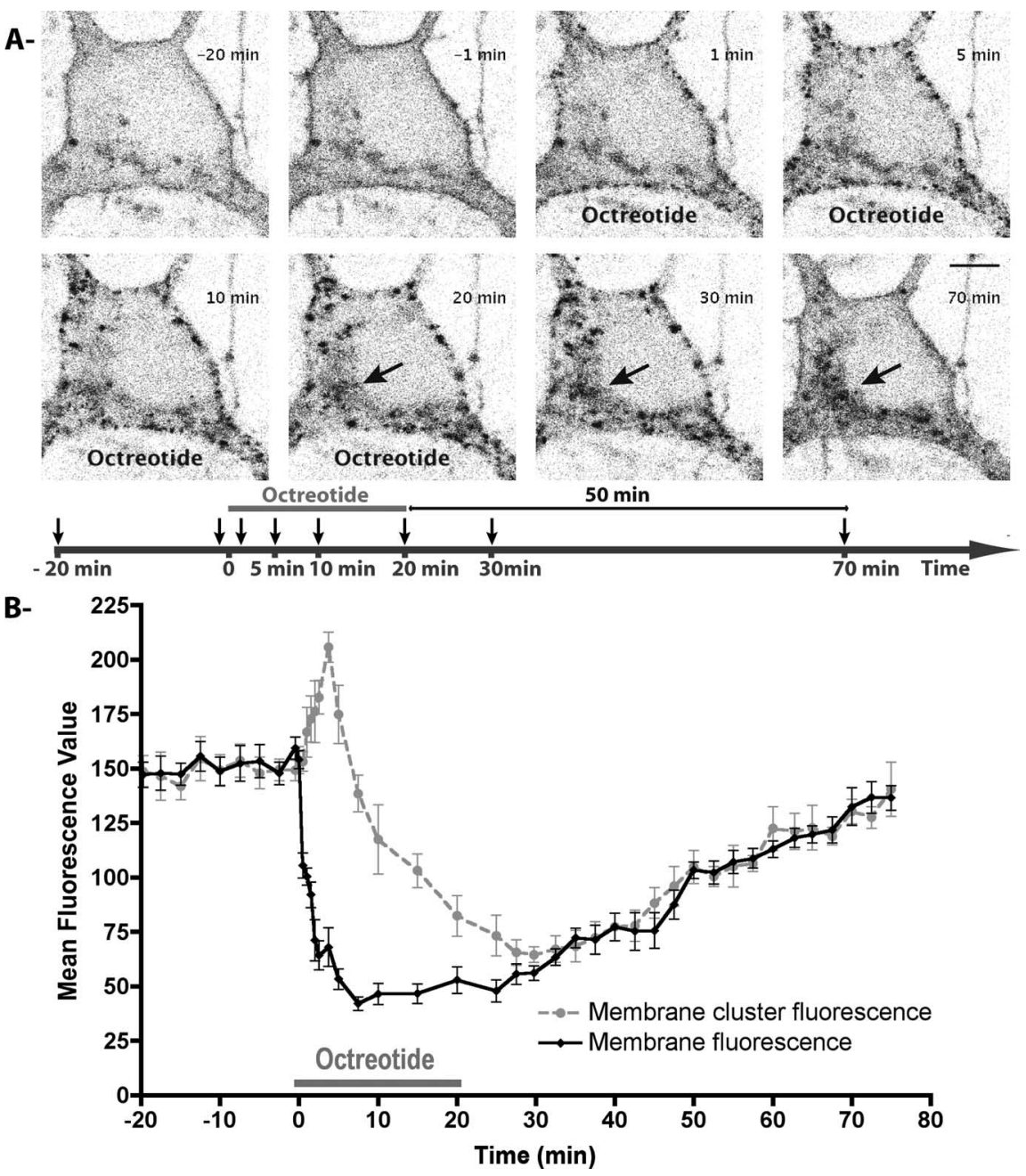

Figure 2. Internalization and recycling kinetics of sst $_{2 \mathrm{~A}}$-EGFP receptors in living neurons. $A, A$ living hippocampal neuron transfected with sst ${ }_{2 A}$ EGFP was observed by confocal microscopy before, during, and after a 20-min-long octreotide treatment quired every $15 \mathrm{~s}$. For each image illustrated, corresponding time is indicated on the timeline below with arrows. Agonist induces clusterization (1 $\mathrm{min}$ ) and internalization $\left(5 \mathrm{~min}\right.$ ) of membrane-associated $\mathrm{sst}_{2 \mathrm{~A}}$ receptors after treatment initiation. From 20 to is again labeled by sst $2 \mathrm{~A}-\mathrm{EGFP}$ at $70 \mathrm{~min}$ (50 min after the end of treatment). Scale bar, $5 \mu \mathrm{m}$. $\boldsymbol{B}$, Graph shows changes in $s t_{2 \mathrm{~A}}$-EGFP fluorescence during the time course of the experiment in subcellular compartments. "Membrane cluster fluorescence" the slow recovery of fluorescence at the plasma membrane with time. Error bars indicate SEM.

stream of the gene coding for a secreted form of alkaline phosphatase. An elevation of intracellular CAMP activates protein kinase A, which translocates in the nucleus to phosphorylate CREB (CRE-binding protein) transcription factors. The latter bind to CRE elements on the gene reporter to proportionally induce the translation of SEAP, which diffuses directly into the supernatant (Durocher et al., 2000; Gupta et al., 2006).

SEAP activity was evaluated using the Great EscAPe SEAP Chemiluminescence kit 2.0 (Clontech) following the protocol provided by the manufacturer. In brief, $\mathrm{CHO}$ cells were transfected with pCRE-SEAP alone or with either the $\mathrm{sst}_{2 \mathrm{~A}}$-WT or $\mathrm{sst}_{2 \mathrm{~A}}$-EGFP in six-well plates using Effectene (Qiagen) and dispatched in 24-well plates after 12-24 h. Cells were starved overnight in serum-free medium, and exposed to stimuli (10 $\mu \mathrm{M}$ forskolin or $10 \mu \mathrm{M}$ forskolin plus $10 \mathrm{~nm}$ OCT) for $4-6 \mathrm{~h}$. Twentyfive microliters of supernatant were transferred in a Nunclon $\Delta$ Surface 96-well plate (Nalge Nunc International, Rochester, NY) in addition of 
A-
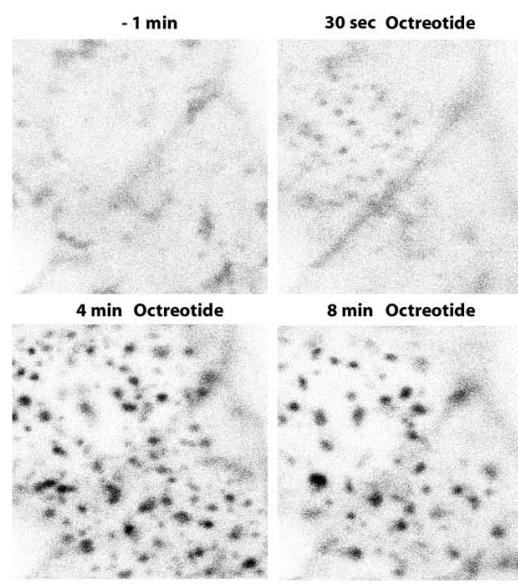

8 min Octreotide

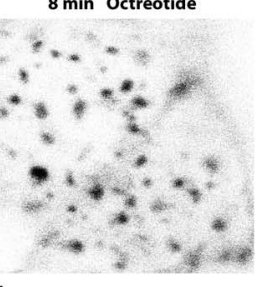

Octreotide
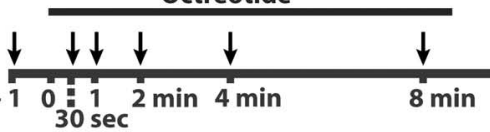

\section{$\min$}

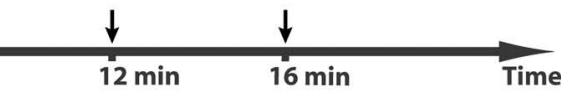

B-

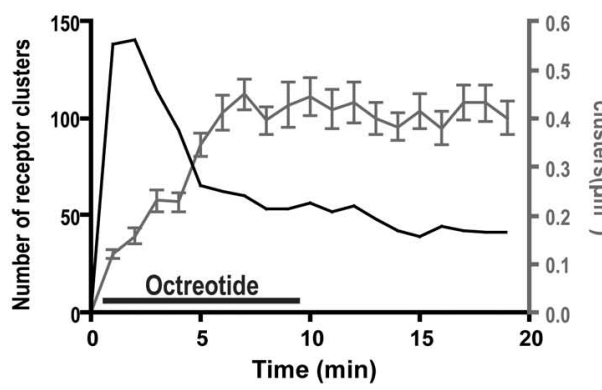

C-

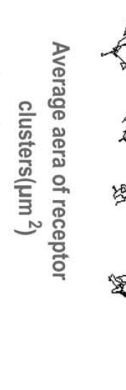

\section{-}
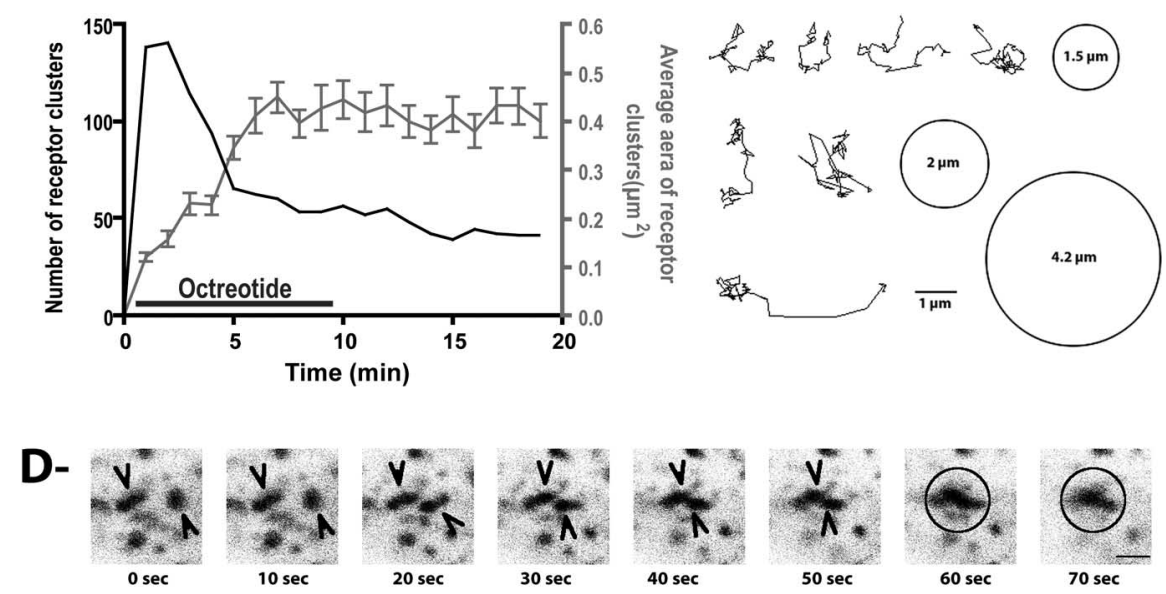

E-
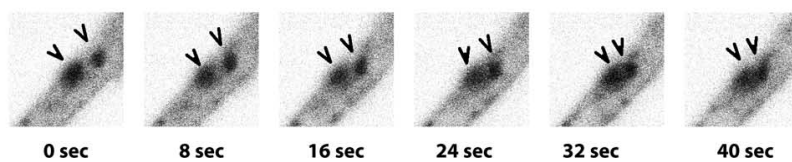

Figure 3. Appearance, movements, and fusion of $\mathrm{sst}_{2 \mathrm{~A}} \mathrm{EGFP}$ clusters after octreotide treatment. $A$, Equatorial confocal images were acquired at the level of a flat portion of the soma membrane during $20 \mathrm{~min}$ and every $10 \mathrm{~s}$, before, during, and after treatment with octreotide (supplemental movie $\$ 4$, available at www.jneurosci.org as supplemental material). For each image illustrated, corresponding time is indicated on the timeline below with arrows. Diffuse sst ${ }_{2 A}-E G F P$ fluorescence is observed at the plasma membrane before agonist treatment. As soon as 30 s after octreotide application, numerous fluorescence clusters become apparent. Scale bar, $2 \mu \mathrm{m}$. B, The graph illustrates the number (black line) and average sizes (gray line) of sst $2{ }_{2 A}$-EGFP clusters depicted in $\boldsymbol{A}$. Note that soon after appearance of receptor clusters, their number decreases while their size increases. Error bars indicate SEM. C, Representative tracks of individual sst $_{2 \mathrm{~A}}$-EGFP clusters monitored immediately after their appearance at the level of the plasma membrane and during $18 \mathrm{~min}$. The circles represent the average range of movement (with diameter inside). Scale bar, $1 \mu \mathrm{m}$. $\boldsymbol{D}, \boldsymbol{E}$, Selected images at the indicated times show representative examples of movement and fusion (circle) of $\mathrm{sst}_{2 \mathrm{~A}}$-EGFP clusters (arrowheads) after 0CT treatment in a soma (D) and a dendrite $(\boldsymbol{E})$ (supplemental movies $\$ 5$, 56 , available at www.jneurosci.org as supplemental material). Scale bar, $1 \mu \mathrm{m}$.

$75 \mu$ l of dilution buffer. The plate was covered with aluminum foil and incubated for $30 \mathrm{~min}$ at $65^{\circ} \mathrm{C}$ in a water bath to eliminate endogenous alkaline phosphatase activity. The samples were cooled on ice for 2-3 min to equilibrate to room temperature. Next, $100 \mu \mathrm{l}$ of SEAP substrate solution was added and incubated for $30 \mathrm{~min}$ at room temperature. The intensity of the chemiluminescence signal was determined by a luminometer (Mediator PhL; Aureon Biosystems GmbH, Vienna, Austria). Assays were performed in triplicate. One-way ANOVA and pairwise
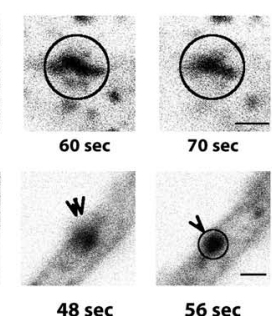

posttest were performed with "treatment" as the independent variable and "cAMP level" as dependent variable $(p<0.05$ was considered statistically significant).

FRAP. For FRAP experiments, neurons $(n=$ 15) expressing EGFP fusion proteins were maintained at $37^{\circ} \mathrm{C}$ in a temperature-controlled chamber at $5 \% \mathrm{CO}_{2}$. Images were obtained using an oil-immersion objective lens (PlanApochromat $63 \times / 1.4$ ) on a Zeiss Observer inverted microscope equipped with a LSM 5 Exciter confocal scanning system (Carl Zeiss, Jena, Germany). A 488-nm laser was used for both imaging and bleaching. The first 10 images of regions of interest (i.e., somatic membrane segments, dendritic membrane segments $50-150 \mu \mathrm{m}$ from the cell body and spine heads) were recorded before bleaching to establish a baseline using $2 \%$ laser power. Membrane areas were then bleached with $100 \%$ laser power for $1 \mathrm{~s}$ (10 cycles) followed by $2 \mathrm{~min}$ postbleached recordings. Fluorescent intensity in the bleached area, which was corrected for bleaching during observation, was measured as a function of time after bleaching, using the AxionVision software FRAP tool (Carl Zeiss). The mobile fraction, the time to half-maximum recovery ( $\mathrm{T}$ half), and the diffusion coefficient were calculated for each curve. Data were processed in Prism (GraphPad Software, San Diego, CA) to generate curve and bar chart and perform statistical analyses. One-way ANOVA and pairwise posttest were performed with "compartment" as the independent variable and "mobile fraction," "half-time maximum recovery," and "diffusion coefficient" as dependent variables ( $p<0.05$ was considered statistically significant).

Confocal microscopy. Confocal microscopy was performed using a Leica DMRA microscope equipped with a $40 \times$ Plan-Apochromat oil immersion lens (numerical aperture, 1.25) and with a Leica SP2 scanning system equipped with Ar $488 \mathrm{~nm}$ and HeNe $543 \mathrm{~nm}$ lasers (Leica Microsystems, Deerfield, IL). To estimate the extent to which transfected $\mathrm{sst}_{2 \mathrm{~A}}$ receptor is overexpressed relative to the endogenous receptor, equatorial confocal sections from cell bodies transfected with the WT sst ${ }_{2 \mathrm{~A}}$ receptor $(n=10$ from three independent experiments) and the EGFP-tagged $\mathrm{sst}_{2 \mathrm{~A}}$ receptor $(n=10$ from three independent experiments) were analyzed and compared with sections obtained from nontransfected neurons $(n=10$ from three independent experiments) immunoreacted with the sst $_{2 \mathrm{~A}}$ receptor antibody. Settings for laser intensity, beam expander, pinhole ( 0.75 Airy unit), range property of emission window, electronic zoom, gain and offset of photomultiplicators, field format, and scanning speed were optimized initially and held constant throughout the study so that all sections were digitized under the same conditions of illumination. NIH ImageJ version $1.38 \mathrm{x}$ software was used to measure mean fluorescence intensities at the plasma membrane of the different cell groups. One-way ANOVA and pairwise posttest were performed with "receptor type" as the independent variable and "mean fluorescence value" as dependent variable $(p<0.05$ was considered statistically significant).

Time-lapse confocal microscopy was performed using the same con- 
focal system equipped with a polycarbonate imaging chamber RC-20 (Warner Instruments, Holliston, MA). The chamber was perfused with isotonic medium supplemented with glucose and HEPES and thermostated at $37^{\circ} \mathrm{C}$ by TC$334 \mathrm{~B}$ dual channel temperature controller (Warner Instruments) with SHM-8 multi-line solution heater (Warner Instruments) and PH-5 heater platform (Warner Instruments). Images were processed using NIH ImageJ.

\section{Results}

To analyze the dynamics of GPCRs with high resolution in living neurons, the $\mathrm{sst}_{2 \mathrm{~A}}$ receptor was tagged at the $\mathrm{C}$ terminus with either EGFP or mCherry. By live-cell confocal microscopy, we found a predominant plasma membrane distribution of $\mathrm{sst}_{2 \mathrm{~A}^{-}}$ EGFP (Fig. $1 A-C$ ) or $s_{2}{ }_{2 \mathrm{~A}}$-mCherry (data not shown) fluorescence in the cell body and the proximal and distal dendrites of hippocampal neurons, a distribution similar to that detected for the wild-type $s_{2} t_{2 \mathrm{~A}}$ receptors using a C-terminally directed antibody (Fig. $1 A-C$ ) or to the endogenous receptor in hippocampal neurons (Csaba et al., 2007). Intracellular fluorescence signal was very low and located mainly in perinuclear compartments. Sequential imaging of confocal stacks was used to further visualize $\mathrm{sst}_{2 \mathrm{~A}}$-EGFP in dendrites. Fluorescence was evident at the membrane of dendritic shafts as well as in heads of dendritic spines (Fig. 1C). Expression levels of transfected $s t_{2 \mathrm{~A}}$-WT receptors and $\mathrm{sst}_{2 \mathrm{~A}}$-EGFP receptors in hippocampal neurons were $\sim 2$.4-fold above the endogenous receptor level (Fig. 1D).

To further determine the effect of fusing EGFP to the $\mathrm{sst}_{2 \mathrm{~A}} \mathrm{C}$ terminus on receptor function, $\mathrm{CHO}$ cells transfected with the wild-type receptor were compared with cells expressing $\mathrm{sst}_{2 \mathrm{~A}}$-EGFP in a cAMP accumulation assay. Forskolin stimulation of CHO cells transfected with pCRE-SEAP alone or cotransfected with pCRE-SEAP and either the $s_{2} t_{2 \mathrm{~A}}-\mathrm{WT}$ or $\mathrm{sst}_{2 \mathrm{~A}}$-EGFP receptor resulted in an approximately twofold increase in cAMP mobilization in the three cell groups, as indicated by the release of SEAP in the culture medium (see Materials and Methods). In the presence of the $\mathrm{sst}_{2 \mathrm{~A}}$ receptor agonist OCT (100 $\left.\mathrm{nM}\right)$, a significant decrease of this forskolinstimulated cAMP mobilization was observed in both $\mathrm{sst}_{2 \mathrm{~A}}$-WT and $\mathrm{sst}_{2 \mathrm{~A}}$-EGFP receptor-expressing cells but not in CHO cells transfected with pCRE- SEAP alone (Fig. $1 E$ ). These results are in accordance with the known negative coupling of the $\mathrm{sst}_{2 \mathrm{~A}}$ receptor to adenylate cyclase through $\mathrm{G}_{\mathrm{i} / \mathrm{o}}$-proteins (Csaba and Dournaud, 2001) and indicate that the addition of the EGFP tag to the $C$ terminus of the receptor does not interfere with the efficient coupling to $\mathrm{G}_{\mathrm{i} / \mathrm{o}}$-proteins.

To determine the mobility of $\mathrm{sst}_{2 \mathrm{~A}}$ receptors at neuronal membranes, FRAP experiments were performed on hippocam-

B-
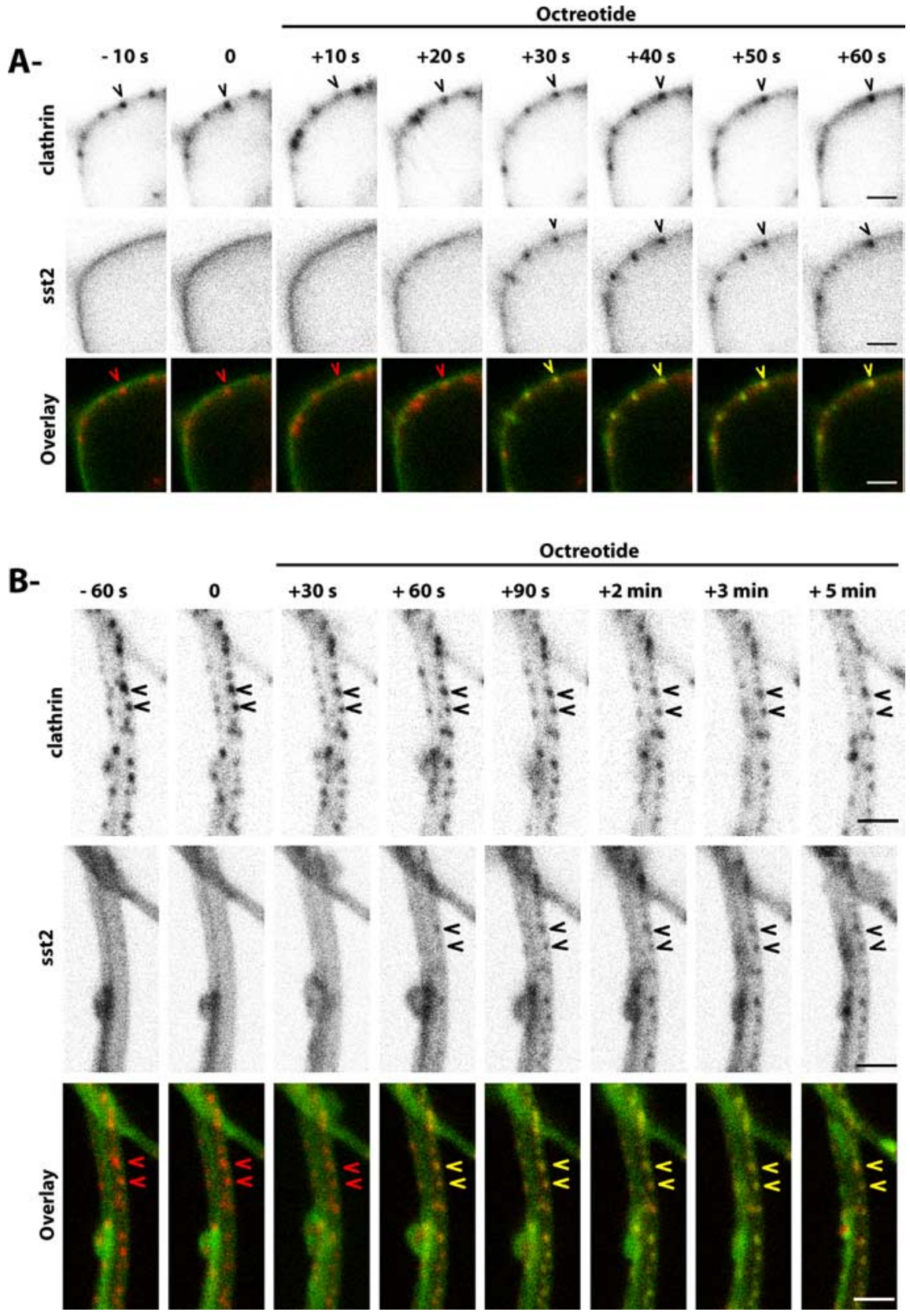

Figure 4. $\quad$ sst $_{2 \mathrm{~A}}-\mathrm{EGFP}$ receptor clusters appear at sites of clathrin-coated pits in soma and dendrites. $A$, Selected images at the indicated times show a representative neuron cotransfected with $\mathrm{sst}_{2 \mathrm{~A}}$ EGFP receptors (green) and Ds-Red clathrin (red) and treated with octreotide (supplemental movieS7, available at www.jneurosci.org as supplemental material). Ds-Red clathrin clusters are visiblenearby the plasma membrane of the soma (arrowhead in top panels and red arrowhead in bottom panels). After octreotide treatment, receptor clusters (arrowhead in middle panels) appear at loci of coated-pitspots (yellow arrowhead in bottom panels). Scale bar, $2 \mu \mathrm{m}$. B, Selected images at the indicated times show a representative dendrite expressing sst $_{2 A}$ EGFP receptors (green) and Ds-Red clathrin (red) and treated with octreotide. Ds-Red clathrin spots are visible nearby the plasma membrane of a dendrite (arrowheads in top panels and red arrowheads in bottom panels). After octreotide treatment, receptor clusters (arrowheads in middle panels) appear at loci of coated-pit spots (yellow arrow in bottom panels). Scale bar, $2 \mu \mathrm{m}$. pal neurons transfected with the sst 2 -EGFP construct (Fig. $1 F-$ $H)$. Fluorescent proteins within defined neuronal subregions [i.e., somatic membranes, dendritic membranes (supplemental movie S1, available at www.jneurosci.org as supplemental material), and spine heads (Fig. $1 F, G)$ ] were photobleached by high intensity laser, and the diffusion of the unbleached into bleached areas was monitored for $2 \mathrm{~min}$. The initial signal recovered to $85.7 \pm 3.7,98.4 \pm 2.0$, and $103.6 \pm 2.3 \%$ in the soma, dendrites, and spines, respectively, indicating that a vast majority of $s^{2} t_{2}$ 


\section{Octreotide}
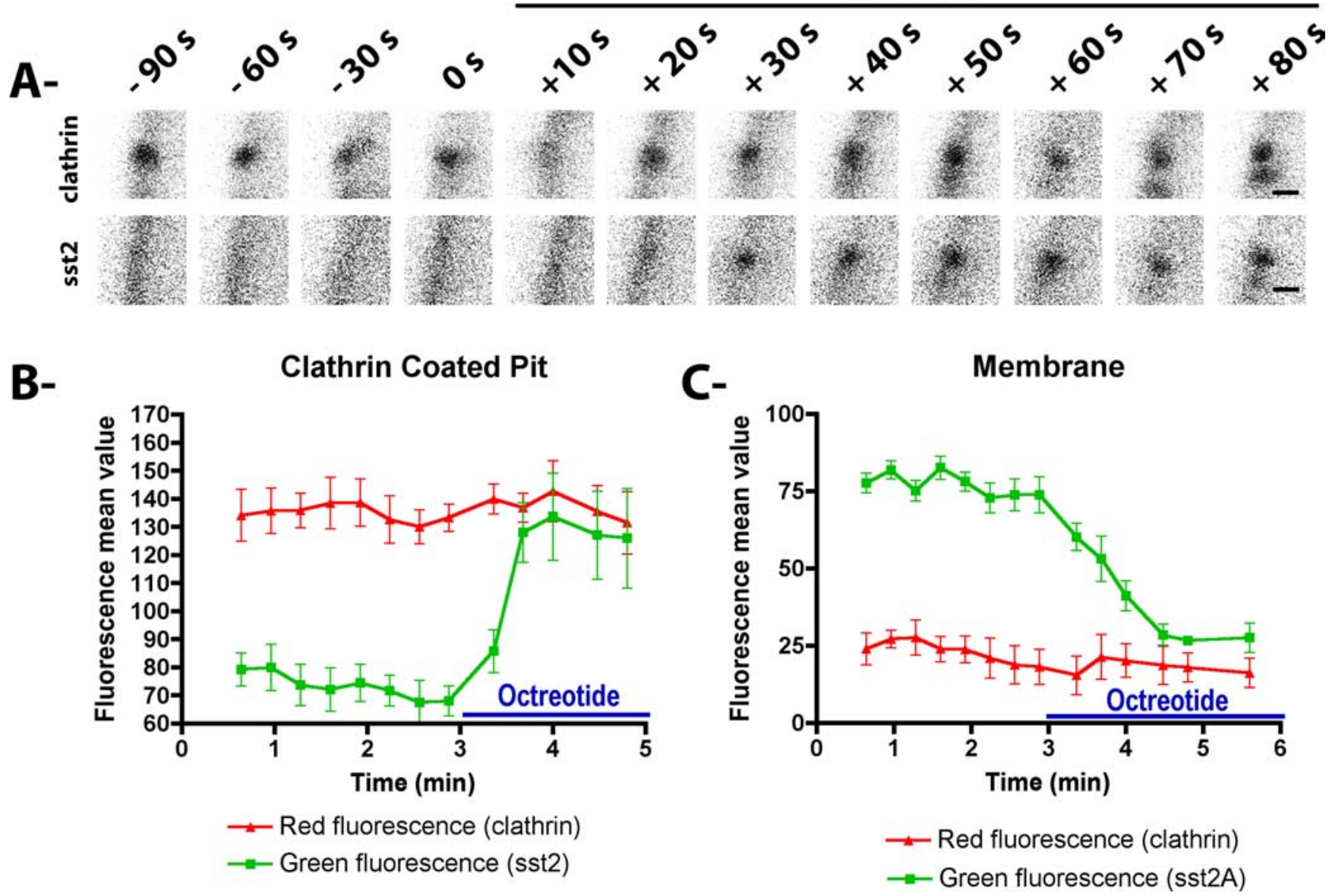

Figure 5. Internalization of $s{ }_{2 A}$-EGFP receptors in preexisting clathrin-coated pits. $A$, Time series showing a representative example of the clusterization of $s t_{2 A}-E G F P$ receptors at the site of an individual preexisting clathrin-coated pit. Scale bar, $0.2 \mu \mathrm{m}$. B, C, Time course of EGFP and Ds-Red fluorescence intensity changes measured at three clathrin-coated pits ( $\boldsymbol{B}$ ) and at three portions of the membrane between clathrin-coated pits $(\boldsymbol{C})$ before and during octreotide application. Note that, after agonist treatment, sst ${ }_{2 \mathrm{~A}} \mathrm{EGFP}$ fluorescence dramatically increases at coated-pit spots and decreases at membrane sites between coated-pit spots. Error bars indicate SEM.

receptor belongs to a mobile fraction (Fig. $1 \mathrm{H}$ ). The mobile fraction was, however, significantly higher in dendrites and spines than in soma. In the three compartments, $T$ half-maximum recovery occurred within the first $2.5 \mathrm{~s}$ after bleaching and the speed diffusion of the mobile $s_{2 \mathrm{~A}}$ receptors was significantly lower in head spines than in somatic membranes (Fig. $1 H$ ). This latter phenomenon is likely attributable to limitation of the diffusion at the spine neck (Ashby et al., 2006). In the three compartments, the observed $\mathrm{sst}_{2 \mathrm{~A}}$ receptor mobility corresponds to lateral diffusion because ( 1 ) the recovery curve fits to the general equation for lateral diffusion, (2) recovery occurred symmetrically from both ends of the bleached region, and (3) the fluorescent signal was homogenous and not punctate (Axelrod et al., 1976; Reits and Neefjes, 2001; Scott et al., 2006).

To investigate the dynamic properties of the $\mathrm{sst}_{2 \mathrm{~A}}$ receptor after agonist activation, individual hippocampal neurons expressing the $s_{2 \mathrm{~A}}$-EGFP and exposed to $1 \mu \mathrm{M}$ SRIF or OCT for 10-20 min were monitored by time-lapse confocal microscopy. One minute after drug application, both $s_{2} t_{2 \mathrm{~A}}$ receptor agonists triggered the appearance of clusters along the membrane of cell bodies and dendrites (Fig. 2A; supplemental movie S2, available at www.jneurosci.org as supplemental material). These receptor clusters then moved toward the cytoplasm. In both proximal and distal dendrites, retrograde movements of receptor clusters were observed in the confocal plane (supple- mental movie S3, available at www.jneurosci.org as supplemental material). Average speed of dendritic receptor clusters was estimated as $10 \mu \mathrm{m} / \mathrm{min}$. At the level of the cell body, as early as 10 min after agonist application, fluorescence converged into a perinuclear compartment extending to the edge of some, but not all, primary dendrites (Fig. $2 \mathrm{~A}$ ). Interestingly, after $70 \mathrm{~min}$, although this perinuclear compartment still displayed $s s_{2 \mathrm{~A}}$-EGFP, diffuse fluorescent signal was again apparent at the cell membrane of the soma, whereas distal dendrites still lacked membrane-associated EGFP fluorescence (Fig. $2 A, B$ ). Three hours after the beginning of the treatment, it became apparent that the entire pool of internalized receptors had quit the intracytoplasmic compartment, and that plasma membrane of both cell bodies and dendrites again displayed high densities of $\mathrm{sst}_{2 \mathrm{~A}}$-EGFP receptors (data not shown).

The kinetics of internalization and recycling, as well as the subcellular distribution of the $s t_{2 \mathrm{~A}}$-EGFP and the $\mathrm{sst}_{2 \mathrm{~A}}$-WT receptors were strikingly comparable as assessed by time course experiments in fixed cells (data not shown), suggesting that, similarly to its lack of effect on subcellular localization and signal transduction, the EGFP tag does not modify the intracellular trafficking of the $\mathrm{sst}_{2 \mathrm{~A}}$ receptor. Receptor internalization induced by SRIF-14 or OCT was totally blocked in the presence of the $s t_{2 \mathrm{~A}}$ receptor antagonist BIM-23627 (data not shown) in accordance 


\section{A- $\beta$-arrestin 1-EGFP}
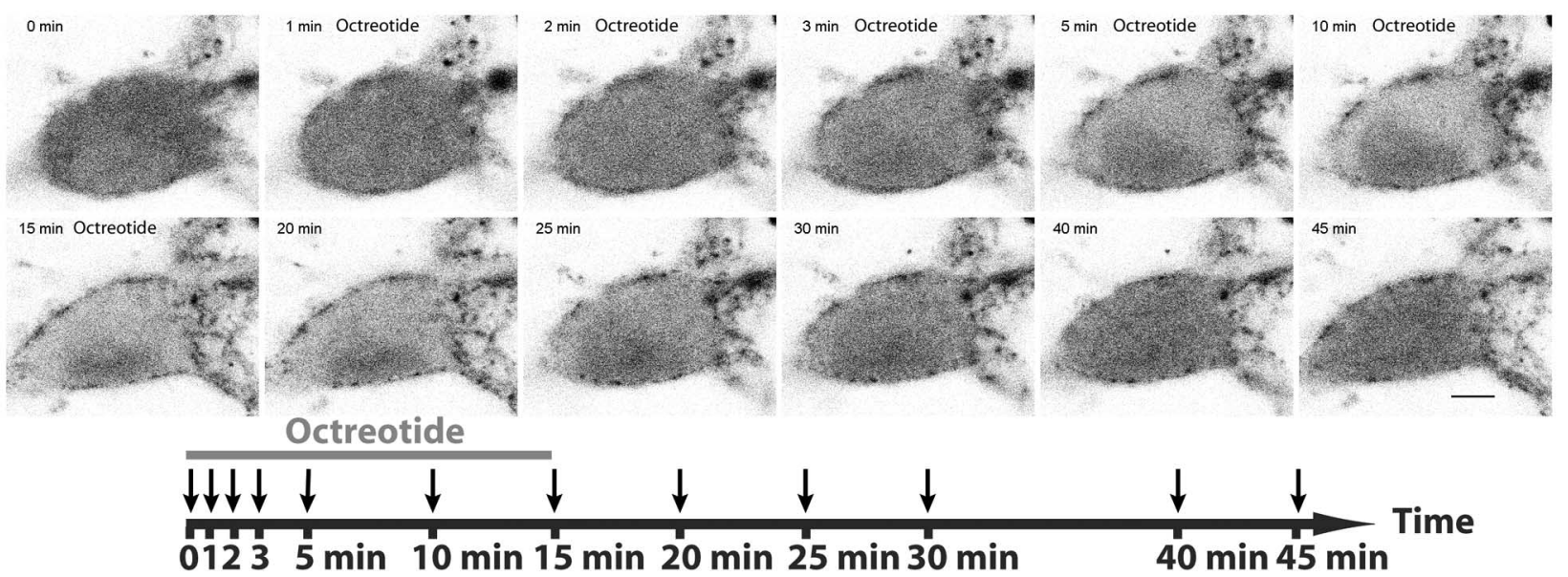

\section{B- $\beta$-arrestin 2-EGFP}
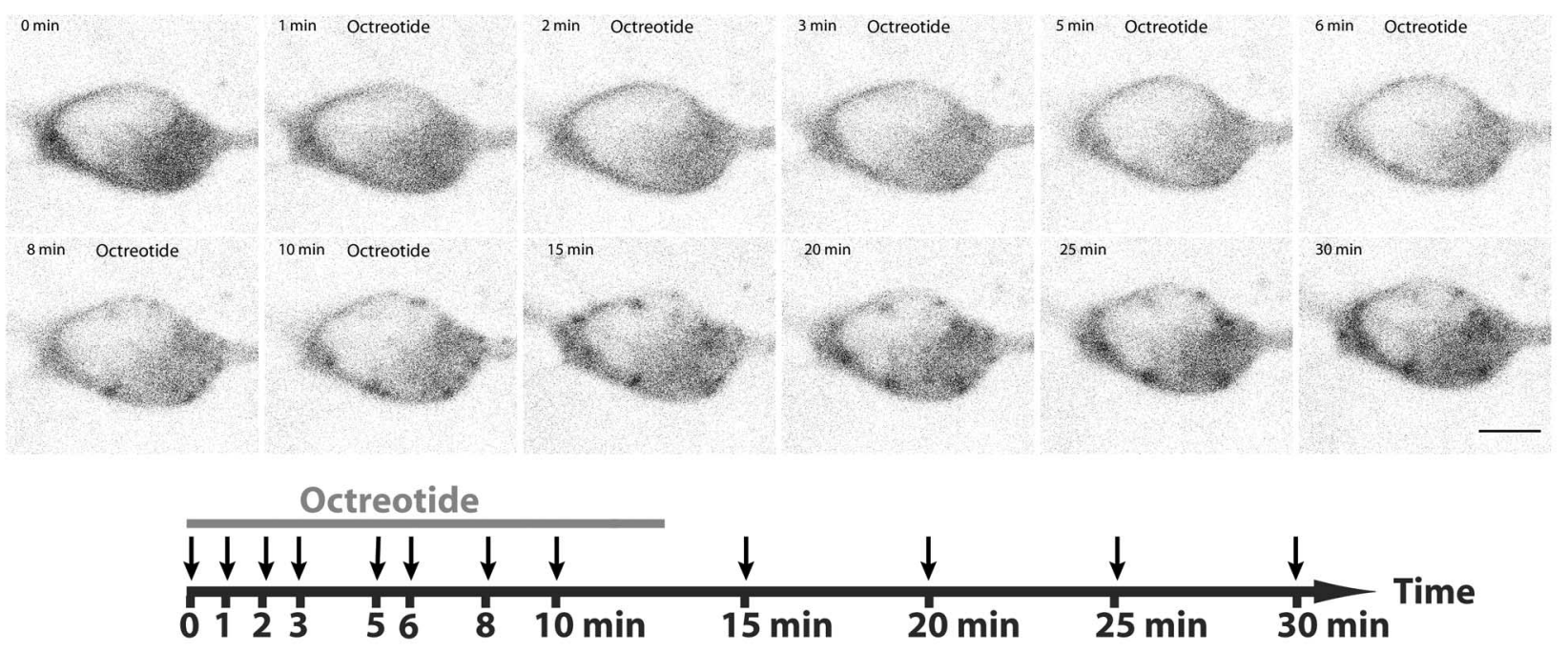

\section{C- $\beta$-arrestin 1-EGFP}

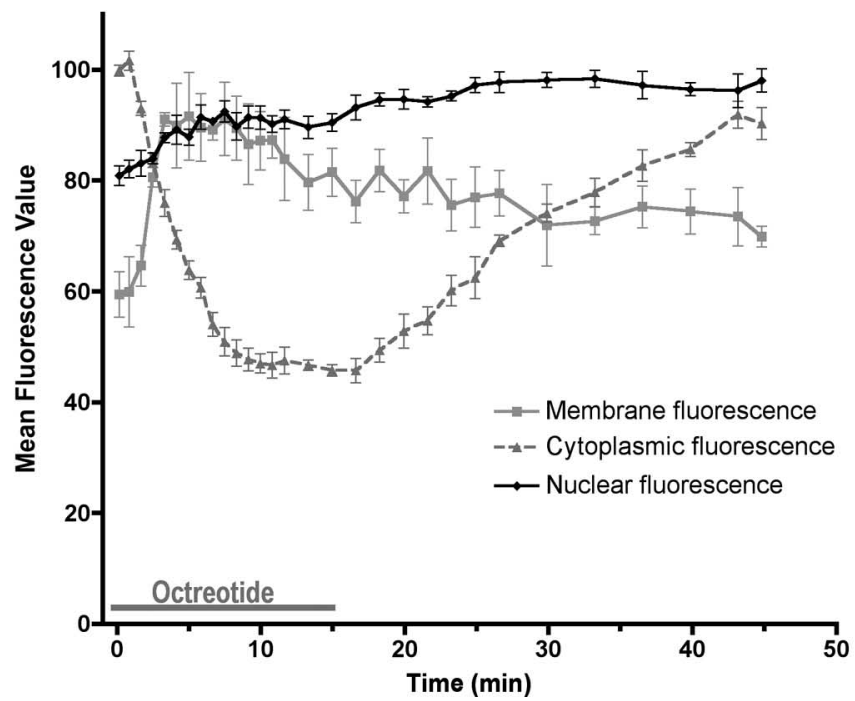

D- $\beta$-arrestin 2-EGFP

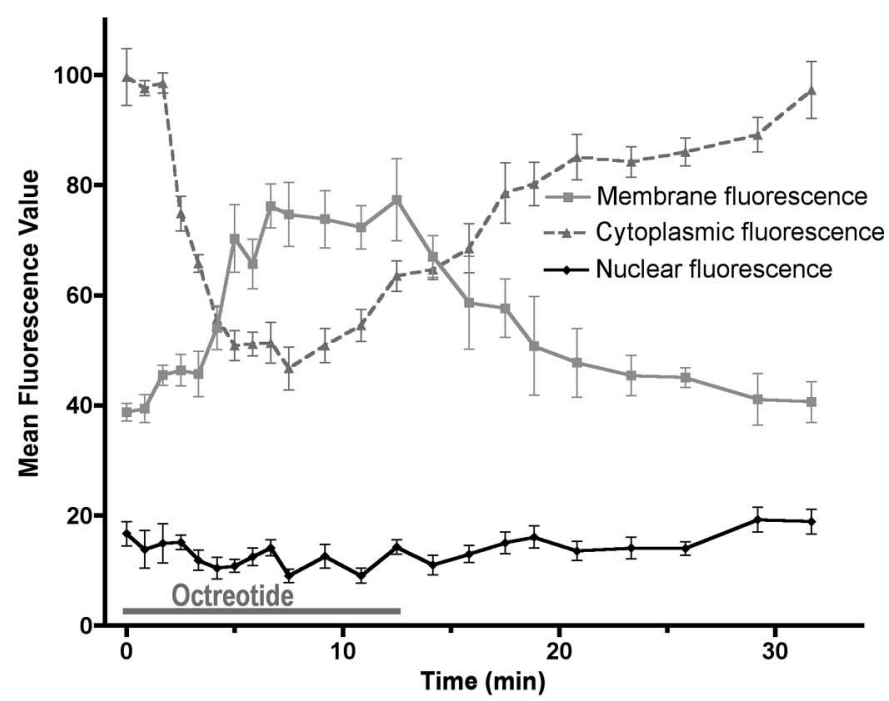

Figure 6. Activation of the sst ${ }_{2 A}$ receptor induces the recruitment of $\beta$-arrestin 1 and 2 at the plasma membrane and the translocation of $\beta$-arrestin 1 in the nucleus in living neurons. To visualize and analyze living neurons coexpressing the sst ${ }_{2 A}$ receptor and $\beta$-arrestin 1 or 2 , neuronal cultures were cotransfected with sst ${ }_{2 A}$-mCheery and $\beta$-arrestin 1-EGFP $(A, C)$ or $\beta$-arrestin 2 -EGFP $(B, D)$. $A$, Distribution of $\beta$-arrestin 1-EGFP by confocal microscopy before, during, and after a 15-min-long octreotide treatment (supplemental movie S8, available at www.jneurosci.org as supplemental material). Equatorial confocal images were acquired every $10 \mathrm{~s}$. For each image illustrated, corresponding time is indicated on the timeline below with arrows. (Figure legend continues.) 


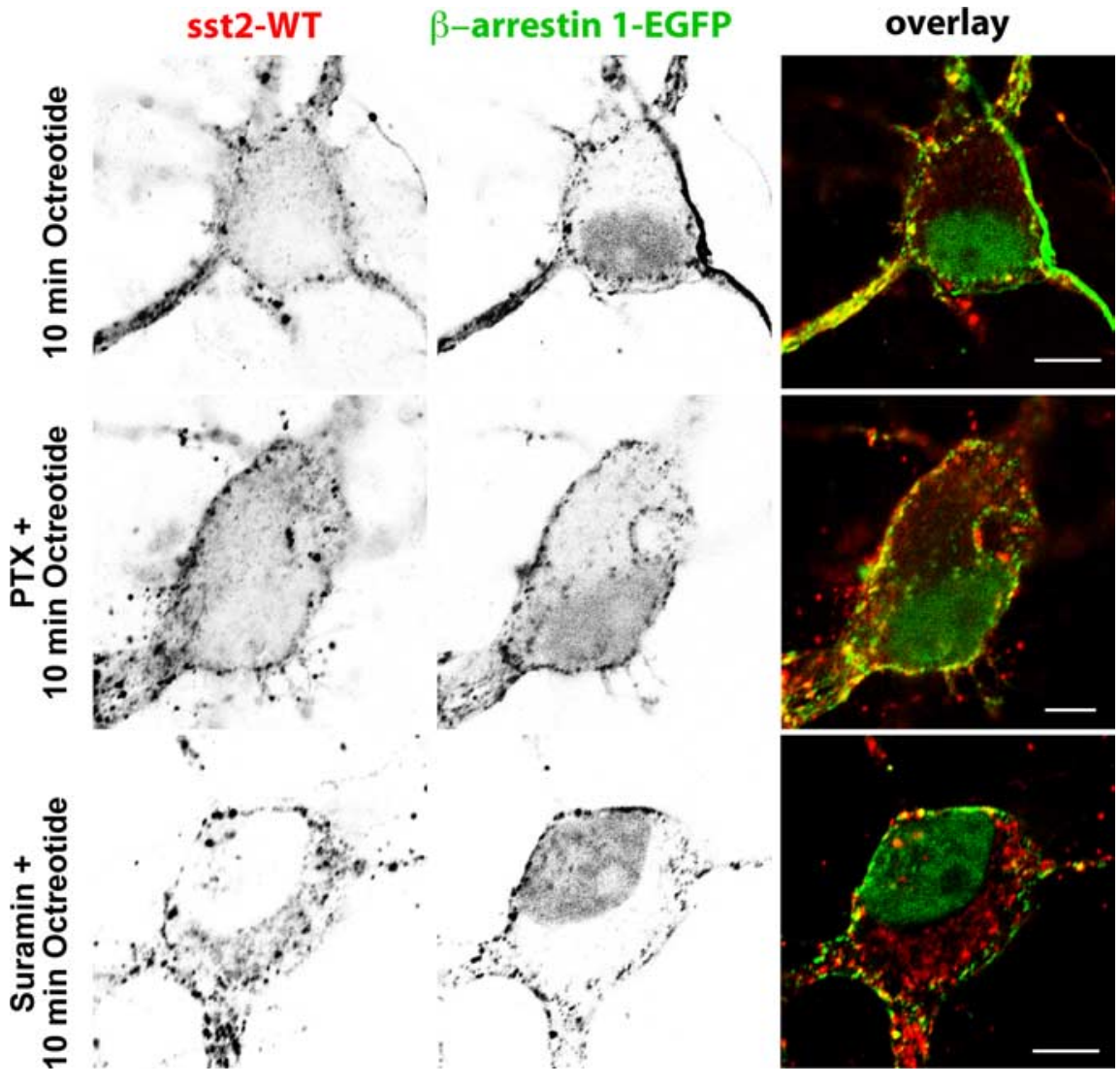

Figure 7. Effect of pertussis toxin or suramin treatment on agonist-induced $\mathrm{sst}_{2 \mathrm{~A}}$ receptor internalization and nuclear accumulation of the $\beta$-arrestin 1. Neurons were cotransfected with plasmids encoding the wild-type receptor (sst ${ }_{2 A}-W T$ ) and the $\beta$-arrestin 1 tagged with EGFP ( $\beta$-arrestin 1-EGFP), treated with PTX for $20 \mathrm{~h}$ or with suramin for 30 min before octreotide treatment and fixed after $10 \mathrm{~min}$. Localization of $\mathrm{sst}_{2 \mathrm{~A}}$ receptors was revealed by immunocytochemistry. Note that pertussis toxin or suramin treatments do not prevent sst $_{2 \mathrm{~A}}$ receptor internalization and nuclear accumulation of the $\beta$-arrestin 1 after agonist stimulation. Scale bar, $5 \mu \mathrm{m}$.

with a previous study (Stumm et al., 2004), demonstrating that internalization was due to agonist binding on the receptor. When BIM-23627 was applied alone, it did not affect the subcellular distribution of the $s \mathrm{st}_{2 \mathrm{~A}}$-WT or $\mathrm{sst}_{2 \mathrm{~A}}$-EGFP receptors (data not shown).

To get insights into early events of receptor dynamics after agonist stimulation, time-lapse confocal images were acquired at high magnification through flat portions of the plasma membrane. We applied image acquisition parameters to ensure a scan thickness of $\sim 500 \mathrm{~nm}$. Perfused buffer with OCT induced rapid $(\sim 10 \mathrm{~s})$ appearance of scattered fluorescence clusters with small surfaces of $\sim 0.1 \mu \mathrm{m}^{2}$ (Fig. $3 A$; supplemental movie $\mathrm{S} 4$, available at www.jneurosci.org as supplemental material). Over time, these receptor clusters increased in size, reaching a plateau of $\sim 0.5 \mu \mathrm{m}^{2} \sim 5 \mathrm{~min}$ after treatment initiation (Fig. $3 A, B$ ). Visual inspection of recorded trajectories of newly formed receptor clusters revealed that the vast majority of them first moved laterally within small domains ( $\sim 5 \mu \mathrm{m}$ in diameter) (Fig. $3 C$ ). In both cell bodies (Fig. 3D; supplemental movie S5, available at www.jneurosci.org as supplemental material) and dendrites (Fig. 3E; supplemental movie S6, available at www.jneurosci.org as supplemental material), multiple fusion events were then visualized, resulting in enlarged fluorescent clusters. The increasing sizes and decreasing densities of $s_{2} t_{2 \mathrm{~A}}$ receptor clusters monitored over time likely reflect both fusion events and movements of clusters from regions nearby the membrane to deep intracytoplasmic compartments.

Because endocytosis of the $s_{2} t_{2 \mathrm{~A}}$ receptor has been hypothesized to occur through a clathrin-dependent mechanism (Csaba et al., 2001), fixed hippocampal neurons transfected with wildtype or EGFP-tagged $s_{2} t_{2 \mathrm{~A}}$ receptor were stained with an anti-clathrin antibody. In both cell bodies and dendrites, receptor clusters induced by agonist treatments extensively colocalized at early times after treatment initiation ( $30 \mathrm{~s}$ to $5 \mathrm{~min}$ ) with a punctate labeling that is characteristic of plasma membrane clathrincoated pits (CCPs) (data not shown). Because it is not known whether activated GPCRs in neuronal cells can trigger the formation of CCPs or whether they clusterized to preexisting CCPs, sst ${ }_{2 \mathrm{~A}}$-EGFP and clathrin-DsRed were coexpressed in neurons and monitored by live-cell confocal microscopy. As previously observed in neuronal (Blanpied et al., 2002) and non-neuronal cells (Santini et al., 2002), clathrin-DsRed appeared as isolated small $(<500 \mathrm{~nm})$ and circular spots scattered at the lower surface of the membrane in both cell bodies and dendrites of mature neurons. A few larger spots were observed, which likely reflect neighboring or clustered CCPs. During the time span studied, most CCPs persisted at specific loci and exhibited restricted mobility $(\sim 0.5 \mu \mathrm{m}$ in diameter). In absence of agonist, the diffuse fluorescence signal of the

$\leftarrow$

(Figure legend continued.) Note that agonist treatment induces a transient redistribution of $\beta$-arrestin 1 fluorescence from the cytoplasm to the plasma membrane. A transient accumulation of $\beta$-arrestin 1-EGFP in the nucleus is also visible. Scale bar, $5 \mu \mathrm{m}$. B, Distribution of $\beta$-arrestin 2-EGFP by confocal microscopy before, during, and after a 13-min-long octreotide treatment. Equatorial confocal images were acquired every $10 \mathrm{~s}$. For each image illustrated, corresponding time is indicated on the timeline below with arrows. Note that agonist treatment induces a transient redistribution of $\beta$-arrestin 2 fluorescence from the cytoplasm to the plasma membrane. Scale bar, $5 \mu \mathrm{m}$. C, Time course of $\beta$-arrestin 1-EGFP fluorescence intensity measured in different subcellular compartments (mean \pm SEM of five measures for each compartment) before, during, and after octreotide application. Note that, after agonist treatment, $\beta$-arrestin 1-EGFP fluorescence rapidly increases at the plasma membrane and in the nucleus and concomitantly decreases in the cytoplasm. Two-way ANOVA with "agonist treatment" and "subcellular compartment" as independent variables, and "fluorescence intensity" as the dependent variable, demonstrates a significant agonist treatment by subcellular compartment interaction $(p<0.0001)$. Partial pairwise comparisons indicated a significant agonist treatment effect in all subcellular compartments, including nucleus $(p<0.0001)$. D, Time course of $\beta$-arrestin 2-EGFP fluorescence intensity measured in different subcellular compartments (mean \pm SEM of five measures for each compartment) before, during, and after octreotide application. Note that, after agonist treatment, $\beta$-arrestin 2 -EGFP fluorescence rapidly increases at the plasma membrane and concomitantly decreases in the cytoplasm. No change is observed in the nucleus. Two-way ANOVA demonstrates a significant agonist treatment by subcellular compartment interaction ( $p<0.0001$ ). Partial pairwise comparisons indicated a significant $(p<0.0001)$ agonist treatment effect in the plasma membrane and cytoplasm but not in the nucleus ( $p=0.33$ ). 

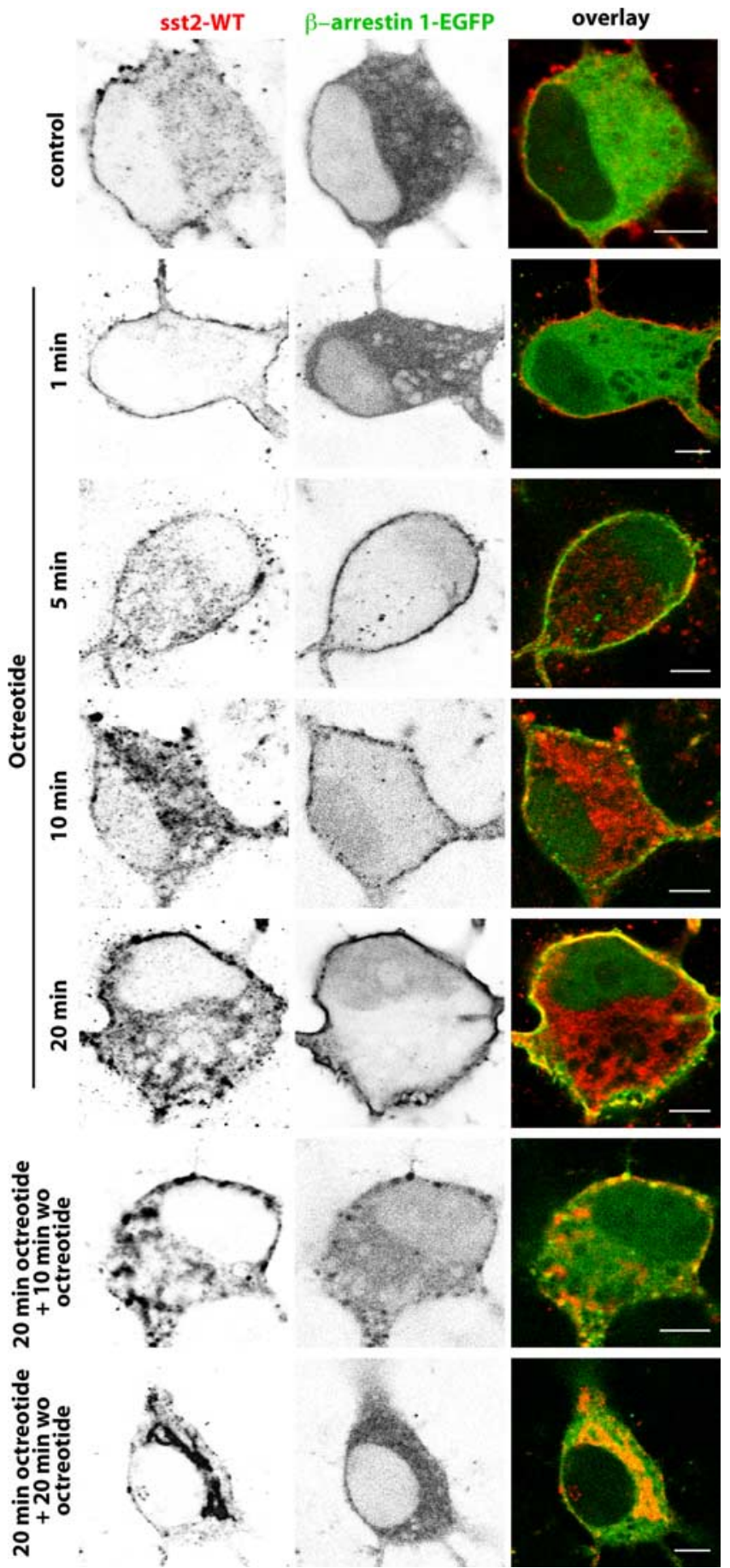

Figure 8. Distribution of $s s_{2 A}-W T$ immunoreactivity and $\beta$-arrestin 1-EGFP fluorescence before, during, and after octreotide treatment in fixed neurons. Neurons were cotransfected with plasmids encoding the wild-type receptor (sst ${ }_{2 \mathrm{~A}} \mathrm{WT}$ ) and the $\beta$-arrestin 1 tagged with EGFP ( $\beta$-arrestin 1-EGFP). Cells were treated with octreotide $(1,5,10$, or $20 \mathrm{~min})$, and then either fixed with paraformaldehyde or rinsed and incubated without octreotide (wo oct) for 10 or $20 \mathrm{~min}$ before fixation. Note that both markers colocalize at the plasma membrane from 5 to $20 \mathrm{~min}$ after agonist treatment initiation and that $\beta$-arrestin 1-EGFP fluorescence is again apparent in the cytoplasm $10 \mathrm{~min}$ after the end of the treatment. Scale bar, $5 \mu \mathrm{m}$.

sst $_{2 \mathrm{~A}}$ receptors observed at the plasma membrane did not colocalize with clathrin-DsRed (Fig. 4A,B; supplemental movie S7, available at www.jneurosci.org as supplemental material). In contrast, the analysis of image series acquired during agonist perfusion revealed that the majority of $\mathrm{sst}_{2 \mathrm{~A}}$-EGFP clus-
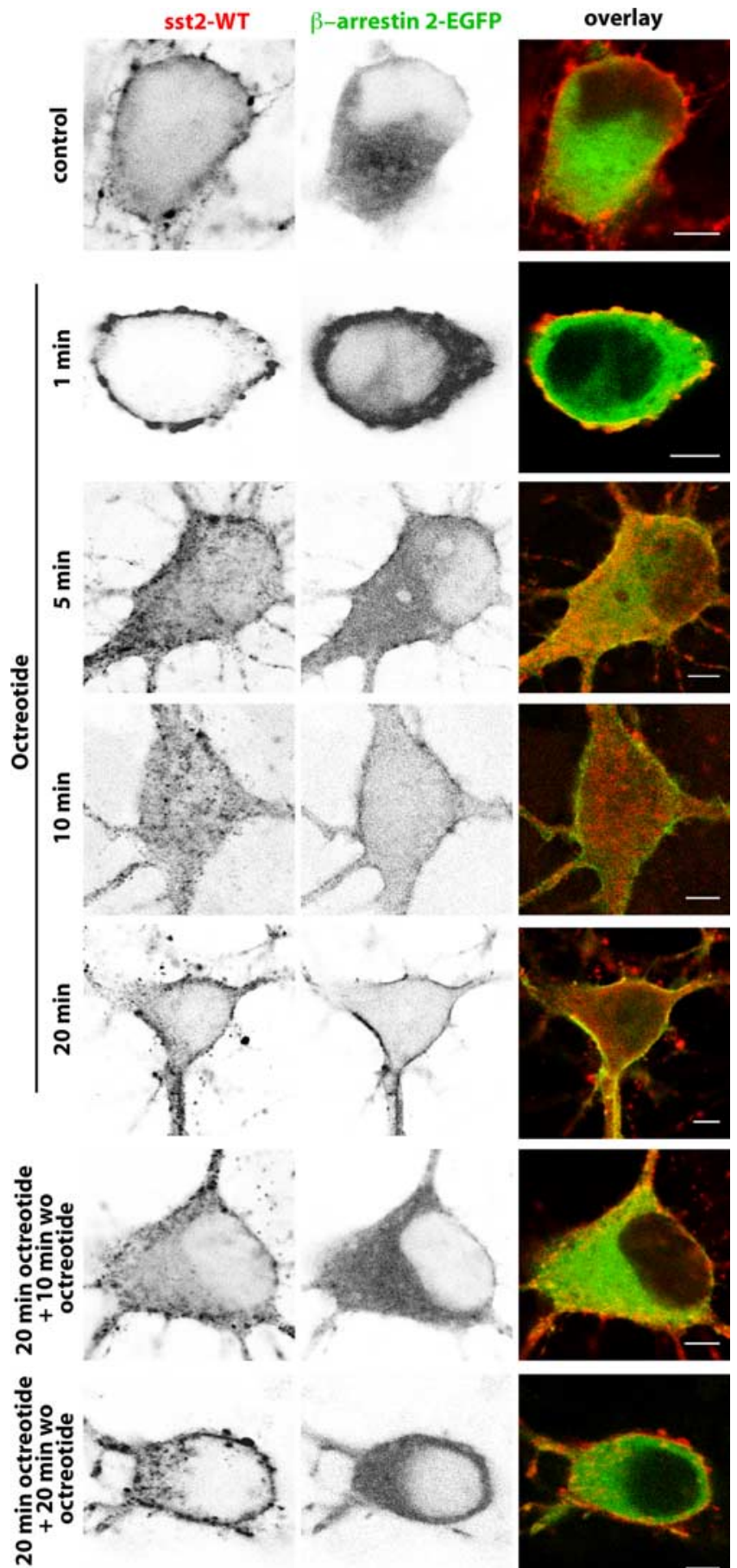

Figure 9. Distribution of $s \mathrm{st}_{2 \mathrm{~A}}-\mathrm{WT}$ immunoreactivity and $\beta$-arrestin 2-EGFP fluorescence before, during, and after octreotide treatment in fixed neurons. Neurons were cotransfected with plasmids encoding the wild-type receptor (sst ${ }_{2 \mathrm{~A}}$-WT) and the $\beta$-arrestin 2 tagged with EGFP ( $\beta$-arrestin 2-EGFP). Cells were treated with octreotide $(1,5,10$, or $20 \mathrm{~min})$, and then either fixed with paraformaldehyde or rinsed and incubated without octreotide (wo oct) for 10 or $20 \mathrm{~min}$ before fixation. Note that both markers colocalize at the plasma membrane from 5 to 20 min after agonist treatment initiation and that $\beta$-arrestin 2-EGFP fluorescence is again apparent in the cytoplasm $10 \mathrm{~min}$ after the end of the treatment. Scale bar, $5 \mu \mathrm{m}$.

ters appeared suddenly at clathrin-DsRed spots ( $n=1379$ of 1398; 98.6\%; five cells) in both cell bodies and dendrites (Fig. $5 A$ ). This finding is expected for receptors that internalize through preexisting CCPs. In an attempt to quantify this phenomenon, red and green fluorescence signals were measured 
at isolated CCPs as well as at membrane portions between CCPs (Fig. 5B). Agonist treatment clearly induced appearance of green fluorescence in CCPs. A concomitant decrease of receptor fluorescence was observed at the plasma membrane between CCPs. Together, these results suggest that membrane-associated receptors move to preexisting CCPs shortly ( $\sim 30 \mathrm{~s})$ after activation. At later time points ( $>5 \mathrm{~min})$, there was a gradual loss of colocalization with clathrin-DsRed, which is likely due to the movement of receptors to intracytoplasmic compartments.

Because in non-neuronal cells targeting of GPCRs to clathrincoated pits via $\beta$-arrestins is well established, we further analyzed the effect of $s_{2} t_{2 \mathrm{~A}}$ receptor activation on the distribution of $\beta$-arrestin 1-EGFP and $\beta$-arrestin 2-EGFP in living hippocampal neurons expressing sst $2 \mathrm{~A}$-WT or $\mathrm{sst}_{2 \mathrm{~A}}$-mCherry. In the absence of agonist, both arrestins were diffusely distributed throughout soma and dendrites (Fig. 6A, B; supplemental movie S8, available at www.jneurosci.org as supplemental material). Moreover, and in contrast to $\beta$-arrestin 2 -EGFP, weak but significant $\beta$-arrestin 1 -EGFP fluorescence was evident in the nucleus. Treatment of cells with receptor agonists SRIF or OCT induced a recruitment of $\beta$-arrestin 1-EGFP and $\beta$-arrestin 2-EGFP to the plasma membrane in both soma and dendrites (Figs. 6-8; supplemental movie S8, available at www.jneurosci.org as supplemental material). After membrane translocation, both arrestins then accumulated in punctate spots scattered throughout the membrane (data not shown). However, a major difference was observed between the two proteins. Indeed, monitoring individual neurons revealed that $\beta$-arrestin 1 -EGFP not only translocates to the cell membrane but also to the nucleus. This phenomenon was not observed for $\beta$-arrestin 2-EGFP. In a first attempt to decipher the intracellular events involved in the translocation of the $\beta$-arrestin 1 to the nucleus, neurons transfected with $\mathrm{sst}_{2 \mathrm{~A}}-\mathrm{WT}$ and $\beta$-arrestin 1-EGFP were preincubated with pertussis toxin to block Gi/o-mediated signal transduction or with suramin to inhibit the GRK2 (Kassack et al., 2000), a kinase involved in $s^{2} t_{2 \mathrm{~A}}$ receptor phosphorylation and $\mathrm{sst}_{2 \mathrm{~A}}$ receptor-mediated $\beta$-arrestin mobilization in non-neuronal cells (Tulipano et al., 2004). These pharmacological treatments did not prevent sst $_{2 \mathrm{~A}}$ receptor internalization and nuclear accumulation of the $\beta$-arrestin 1 after agonist stimulation (Fig. 7), suggesting that other proteins and pathways, which remained to be determined, are involved in the $\mathrm{sst}_{2 \mathrm{~A}}$ receptormediated translocation of $\beta$-arrestin 1 to the nucleus.

The analysis of $\beta$-arrestin kinetics further demonstrates that arrestins transiently accumulate in small vesicles carrying the receptor at the vicinity of the cell membrane in living and fixed neurons coexpressing $\beta$-arrestin 1- or 2 -EGFP and $s_{2} t_{2 \mathrm{~A}}$-WT or $\mathrm{sst}_{2 \mathrm{~A}}-\mathrm{mCherry}$. In contrast to the $\mathrm{sst}_{2 \mathrm{~A}}$ receptor, neither arrestins were apparent in the course of time in large intracytoplasmic vesicles (Figs. 8,9 ). This suggests that a dissociation of $\beta$-arrestins from the receptor occurs early (5-10 min) during the time course of the endocytic events. The distribution of fluorescence signals of both $\beta$-arrestin 1-EGFP and $\beta$-arrestin 2-EGFP was similar to that of untreated cells $20 \mathrm{~min}$ after the end of the agonist treatment.

To further analyze postendocytic pathways of the sst $_{2 \mathrm{~A}}$ receptor, hippocampal neurons expressing the $s_{2} \mathrm{2A}_{\mathrm{A}}$-WT receptor were fixed at different times after SRIF and OCT stimulation and processed for immunolocalization of various intracellular compartments (Fig. 10). From 5 to 15 min after agonist treatment, intracytoplasmic vesicles expressing the receptor colocalized extensively with both the EEA1 and the TfR. EEA1 is a membrane-bound protein essential for fusion between primary
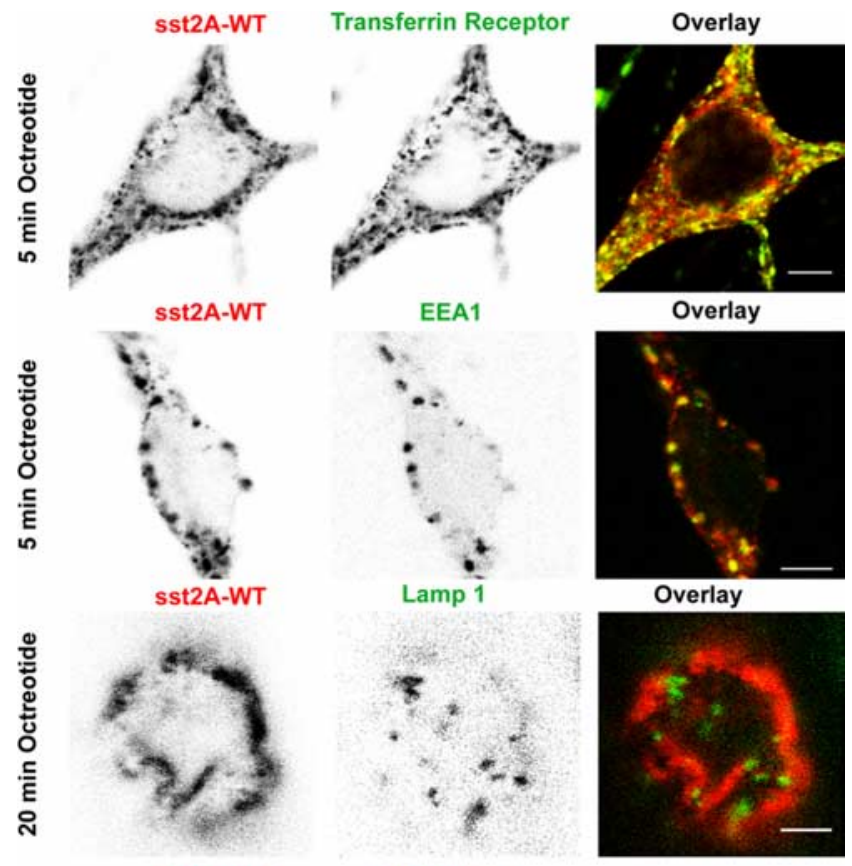

Overlay
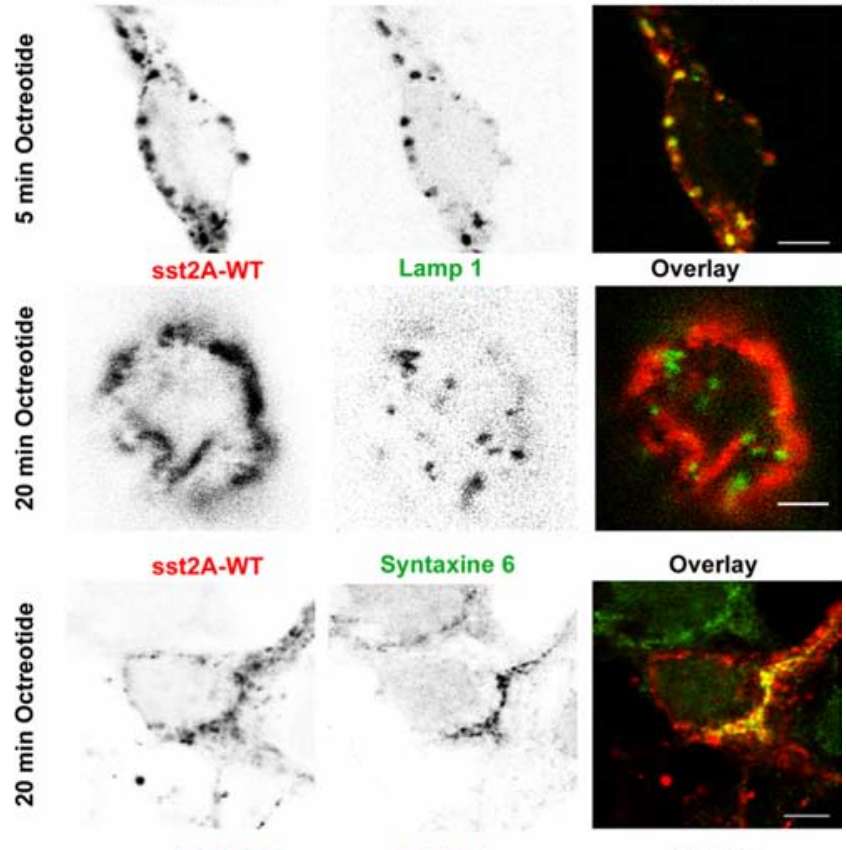

Syntaxine 6
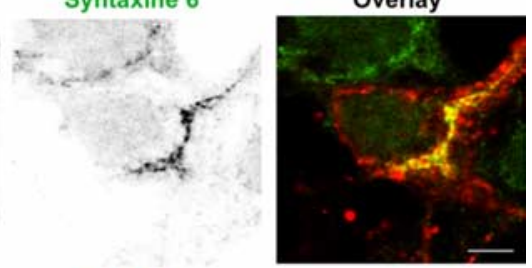

sst2A-WT
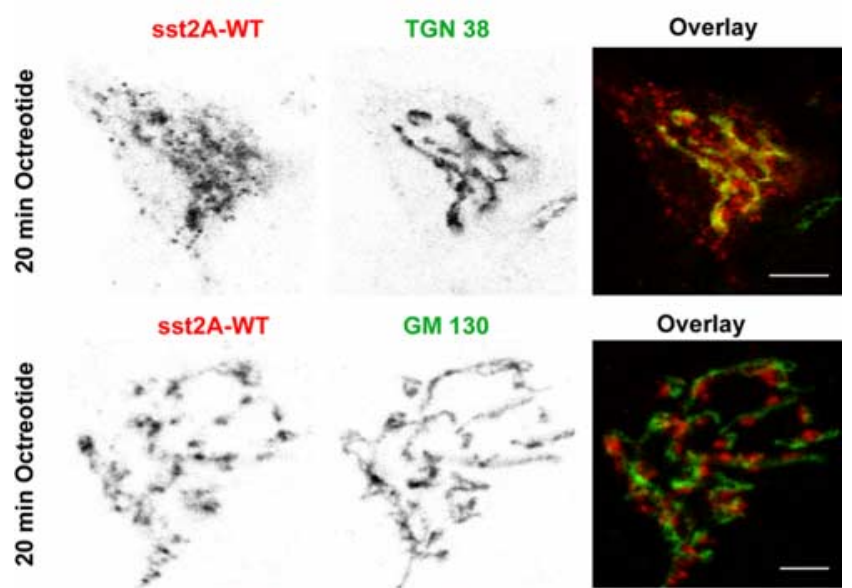

Overlay

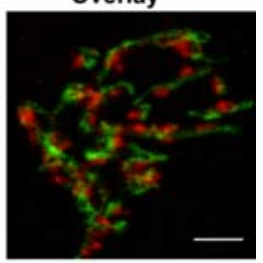

PDI
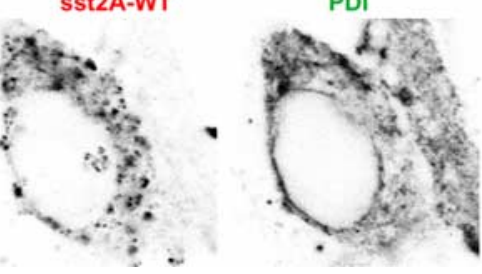

Overlay

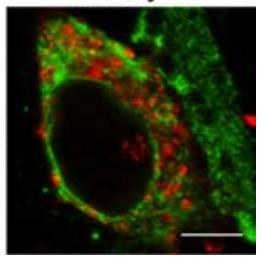

Figure 10. Confocal microscopic analysis of sst $_{2 \mathrm{~A}}$ receptor and Golgi, endosomal, or ER markers immunoreactivity in fixed neurons treated with octreotide. Neurons were transfected with the plasmid encoding the wild-type receptor (sst ${ }_{2 \mathrm{~A}}-\mathrm{WT}$ ), treated with octreotide, and fixed at different times after initiation of the treatment. After fixation, localization of $s_{2 \mathrm{~A}}$ receptors and various intracellular markers was revealed by immunocytochemistry. After 5 min of agonist treatment, clusters of internalized receptors colocalize with transferrin receptor and EEA1, two markers of early endosomes. Twenty minutes after the addition of octreotide, $s_{2 A}{ }_{2 A}$ receptors do not colocalize with the late endosome/lysosome marker LAMP-1 but overlap with trans-Golgi markers syntaxin 6 and TGN38. № colocalization was observed with the cis-Golgi marker GM 130 or the ER marker PDI. Scale bars: $5 \mu \mathrm{m}$; except for sst $_{2 \mathrm{~A}}$-WT/GM130 and sst $_{2 \mathrm{~A}}$-WT/Lamp-1, $3 \mu \mathrm{m}$. 
endocytic vesicles and sorting endosomes (Simonsen et al., 1998; Christoforidis et al., 1999). TfR, a recycling membrane protein, is a well characterized marker of the early endocytic compartment, which is composed of sorting and recycling endosomes (Mukherjee et al., 1997; Maxfield and McGraw, 2004). Studies in living cells have demonstrated that TfR molecules do not enter the late endosomal compartment (Gruenberg and Maxfield, 1995). Together, these results suggest that, after activation, $s s t_{2 \mathrm{~A}}$ receptors are routed to sorting and recycling endosomes but not to the late endosomal pathway. Accordingly, at later time after agonist treatment, internalized receptors were never found to colocalize with the LAMP-1, a well characterized marker of late endosomes and lysosomes (Griffiths et al., 1988; Nazarian et al., 2003). Twenty minutes after the agonist treatment initiation, $\mathrm{sst}_{2 \mathrm{~A}}$ receptors concentrated in a perinuclear compartment displaying a vesiculotubular structure. Colocalization experiments demonstrated that this compartment expresses markers of the trans-Golgi [i.e., the trans-Golgi network-specific integral protein TGN38 and the $t$-SNARE ( $t$-soluble $N$-ethylmaleimide-sensitive factor attachment protein receptor) syntaxin 6]. The later protein is involved in endosome to transGolgi transport (Bock et al., 1996, 1997; Mallard et al., 2002). In contrast, internalized $\mathrm{sst}_{2 \mathrm{~A}}$ receptors never enter the cis-Golgi or the endoplasmic reticulum (ER) compartments because colocalization with GM130 or PDI were not observed. In agreement with this latter observation, pretreatment of cells with the protein synthesis inhibitor cycloheximide did not prevent the accumulation of $\mathrm{sst}_{2 \mathrm{~A}}$ receptors in the transGolgi (Fig. 11). This suggests that these receptors derive from the pool of internalized receptors and are not newly synthesized receptors. In addition, treatment with the microtubule-depolymerizing agent, colchicine, abolished the long-range translocation of the $\mathrm{sst}_{2 \mathrm{~A}}$ receptors to the trans-Golgi. Under colchicine treatment, receptors remained trapped in intracytoplamsic vesicles expressing TfR and EEA1 in both cell bodies and dendrites (Fig. 11). Targeting of receptor cargo from sorting and recycling endosomes to the trans-Golgi compartment appears therefore dependent on a microtubule-based process.

\section{Discussion}

Compared with the large number of studies dealing with GPCR signaling, GPCR dynamics under resting conditions or after agonist activation are mostly unexplored in vivo, especially in neuronal cells. Here, we developed a live-cell imaging approach to gain insights into the dynamics of a GPCR in living neurons, using the somatostatin receptor $\mathrm{sst}_{2 \mathrm{~A}}$ as a receptor model. Several complementary experiments argue for the fact that the $s_{2} \mathrm{AA}$ EGFP construct is a valuable tool for such dynamic studies. Indeed, the EGFP-tagged receptor displayed the same subcellular localization as the wild type or the endogenous $\mathrm{sst}_{2 \mathrm{~A}}$ receptor (Csaba et al., 2007) (i.e., homogeneously distributed at the plasma membrane of the somatodendritic domain including spines). In addition, the $s_{2} t_{2}$-EGFP remains efficiently coupled to the $G_{i / o}$ signal transduction pathway and displays the same intracellular trafficking (kinetics of internalization and recycling, localization in intracellular compartments) as the wild-type receptor.

Our experiments led to four key findings. First, using FRAP experiments we found that the $s_{2} t_{2 \mathrm{~A}}$ receptor is mobile and laterally and rapidly diffuse in neuronal membranes. Second, receptor activation triggers the recruitment of $\beta$-arrestin 1 and 2 to the plasma membrane and the translocation of the $\beta$-arrestin 1 to the nucleus. Although the receptor was found to recycle slowly, dissociation from $\beta$-arrestins occurs early in the endocytic process. Third, endocytosis of membrane-associated receptors is due to clusterization in preexisting CCPs in neurons. Fourth, through repetitive fusion events, receptor cargo becomes concentrated in fewer and larger early endosomes before being targeted to a transGolgi compartment. Together, these results provide a comprehensive view of a GPCR postendocytic trafficking in living neurons and establish an alternative route for receptor recycling (Fig. 12).

The $s_{2 \mathrm{~A}}$ diffuses rapidly within the plasma membrane as demonstrated using FRAP analysis of fluorescently tagged receptors. In addition, the percentage of the mobile fraction is very 


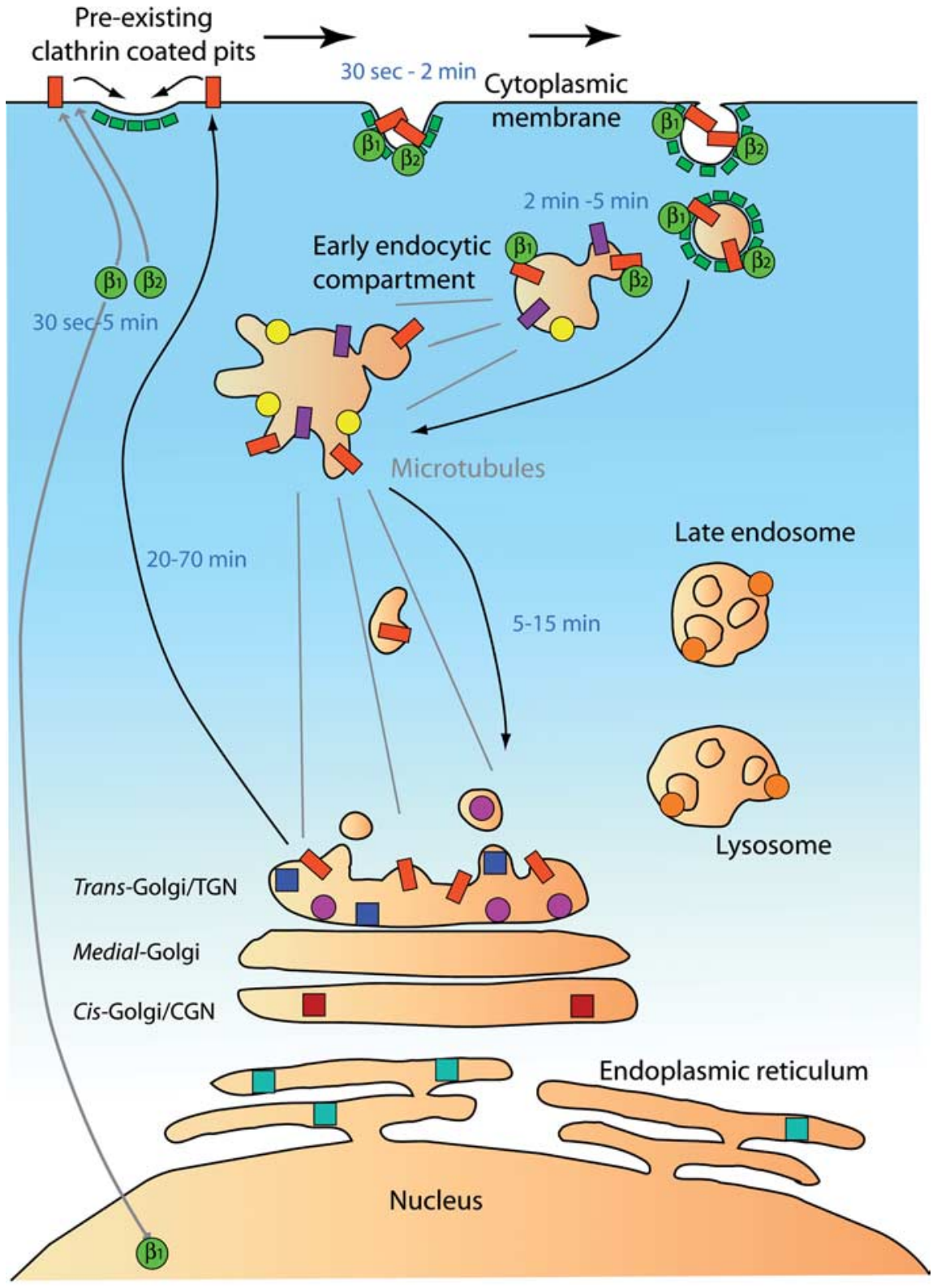

\begin{tabular}{|lll|}
\hline Sst2A Receptor & $\bigcirc$ EEA1 & PDI \\
Transferrin Receptor & $\bigcirc$ LAMP1 & Sst2A receptor trafficking \\
(B) $\beta$ Arrestin 1 & Syntaxin 6 & S arrestin movement following \\
(B2) $\beta$ Arrestin 2 & $\square$ TGN 38 & sst2A receptor activation \\
$\square$ Clathrin & $\square$ GM 130 & \\
\hline
\end{tabular}

Figure 12. Proposed model for intracellular trafficking of $s t_{2 \mathrm{~A}}$ receptor after agonist activation in living neurons. First, receptor activation triggers the recruitment of $\beta$-arrestin 1 and $\beta$-arrestin 2 at the plasma membrane and the translocation of the $\beta$-arrestin 1 to the nucleus. Second, endocytosis of membrane-associated receptors is attributable to clusterization of receptors in preexisting CCPs. Third, through repetitive fusion events, receptor cargo becomes highly enriched in fewer and larger early endosomes before being targeted to a trans-Golgi compartment by a microtubule-dependent process (gray lines). Finally, $\mathrm{sst}_{2 \mathrm{~A}}$ receptor recycles back to the plasma membrane. Markers of the different intracellular compartments used in this study and time range (from beginning of the agonist treatment) for each main step are specified.

high $(>85 \%)$ in the three cellular compartments studied. The diffusion characteristics of the $\mathrm{sst}_{2 \mathrm{~A}}$ is similar from those reported for other GPCRs in extrasynaptic sites, such as the serotonin $5 \mathrm{HT}_{1 \mathrm{~A}}$ (Pucadyil and Chattopadhyay, 2007) and dopamine $\mathrm{D}_{1}$ (Scott et al., 2006) receptors. In spines, although the sst $_{2 \mathrm{~A}}$ recep- tor has been shown to potentially interact with scaffolding proteins of the postsynaptic density Shank1 and ProSAP1/CortBP1 (Zitzer et al., 1999a,b), our results indicate that, in resting conditions, only a minor portion of sst $_{2 \mathrm{~A}}$ receptors might be associated with cytoskeletal anchoring proteins. However, such interactions often occur when the receptor is stimulated, as previously demonstrated for the sst ${ }_{2 \mathrm{~A}}$ and ProSAP1/CortBP1 (Zitzer et al., 1999a) or for the $\beta$-adrenergic receptor and the PDZ (postsynaptic density-95/Discs large/zona occludens-1) domain of the regulatory factor of the $\mathrm{Na}^{+} / \mathrm{H}^{+}$exchanger (Hall et al., 1998), and could serve to modulate receptor internalization and/or postendocytic trafficking. Additional studies are clearly needed to ascertain the physiological role of the interactions between the $\mathrm{sst}_{2 \mathrm{~A}}$ receptor and scaffolding proteins at the postsynaptic density.

$\beta$-Arrestin 1 and 2 are well known negative regulators of GPCR signaling. In addition, they act as scaffolds to recruit endocytic proteins and to activate various signaling pathways such as the MAPK (mitogen-activated protein kinase) cascades. More recently, it has been demonstrated that they also facilitate the degradation of the immediate signaling molecules produced by an activated receptor (Perry et al., 2002; Nelson et al., 2007). The present study illustrates that the activation of $\mathrm{sst}_{2 \mathrm{~A}}$ receptors in neurons induces the translocation of $\beta$-arrestin 1 and 2 from the cytoplasm to the plasma membrane of cell bodies and dendrites. This is in agreement with the presence of serine/threonine clusters in the $\mathrm{C}$-terminal tail of the receptor that are mandatory for its interaction with $\beta$-arrestins (Tulipano et al., 2004). Therefore, the $s_{2 \mathrm{~A}}$ most likely belongs to the class $\mathrm{B}$ receptors (such as substance $\mathrm{P}$ or AT1a receptors) that display similar affinities for $\beta$-arrestin 1 and $\beta$-arrestin 2 rather than to the class A receptors (such as $\mu$-opioid or $\beta 2$ ) that have a higher affinity for $\beta$-arrestin 2 than for $\beta$-arrestin 1 (Ferguson, 2001; Gainetdinov et al., 2004). Although $\beta$-arrestins translocate to the activated $\mathrm{sst}_{2 \mathrm{~A}}$ receptor in punctated area of the plasma membrane, both arrestins dissociate rapidly from the receptor $(5-10$ min) after agonist activation. Therefore, arrestins only transiently accumulate in the endosomal compartment expressing EEA1 and TfR but not in TGN38 and syntaxin 6 expressing ones. In contrast to other receptor types such as neurokinin 1 receptor (Grady et al., 1995; McConalogue et al., 1999), the rapid dissociation of the $s s t_{2 \mathrm{~A}}$ from $\beta$-arrestins does not imply rapid receptor recycling. Together, these findings suggest that the recruitment of 
$\beta$-arrestins is more important for early endocytic events of the sst $_{2 \mathrm{~A}}$ receptor than for its postendocytic fate.

Of particular interest is the observation that agonist activation of the $s_{2 \mathrm{~A}}$ in neurons, in contrast to non-neuronal cells ( $\mathrm{Tu}$ lipano et al., 2004), triggers the translocation of $\beta$-arrestin 1 to the nucleus. Only few receptors (such as $\delta$ - and $\kappa$-opioid receptors) were observed to induce such a phenomenon (Kang et al., 2005) and direct demonstration of this phenomenon in neurons was lacking. After translocation to the nucleus of HEK293 cells, $\beta$-arrestin 1 forms scaffolds for transcription factors at the promoters of target genes and thereby regulates transcription directly (Kang et al., 2005). Our results therefore suggest that $\beta$-arrestin 1 could serve as a nuclear messenger for the $\mathrm{sst}_{2 \mathrm{~A}}$ receptor in neurons. Additional investigations are needed to define the nuclear targets of the $s \mathrm{st}_{2 \mathrm{~A}}$ receptor activated through this new putative pathway, and whether they differ or not from the ones activated by $\delta$ - and $\kappa$-opioid receptors.

After agonist treatment, live-cell imaging of the EGFP-tagged $\mathrm{sst}_{2 \mathrm{~A}}$ receptor and clathrin Ds-red are consistent with the fact that receptors accumulate in preformed CCPs rather than inducing the formation of new clathrin domains. This observation is in agreement with the finding that clathrin coats reside in stable, long-lasting zones in mature neurons (Blanpied et al., 2002). Interestingly, the vast majority, if not all, of the preformed CCPs in dendrites and cell bodies colocalize with the $s_{2 \mathrm{~A}}$ at early time points after agonist challenge. This suggests that receptor cargo does not distinguish between putative compositionally distinct CCP subsets as shown in the HEK293 cells (Puthenveedu and von Zastrow, 2006). Because $\beta$-arrestin 1 and 2 first colocalize with the receptor at the plasma membrane and then colocalize with both the receptor and clathrin at hot spots, the receptor appears to be mobilized to CCPs together with $\beta$-arrestins. This is in accordance with the proposed function of these proteins as adaptors that connect GPCRs to the endocytic machinery (Ferguson, 2001; Gainetdinov et al., 2004). Internalization of GPCR- $\beta$ arrestin complex into preexisting CCPs, which has been only reported in epithelial cell lines (Santini et al., 2002; Scott et al., 2002), appears therefore to be a shared mechanism for a large variety of mammalian cells including neurons.

A short time after internalization through CCPs, multiple fusion events of $s t_{2 \mathrm{~A}}$-EGFP clusters were visualized, resulting in enlarged fluorescent vesicles, in both cell bodies and dendrites. This event likely reflect heterotypic fusion between plasma membrane clathrin-coated vesicles and early endosomes carrying $\mathrm{sst}_{2 \mathrm{~A}}$ cargo, as well as homotypic fusion between early endosomes carrying the receptor (Robinson et al., 1996; Woodman, 2000; Zerial and McBride, 2001). Accordingly, receptor cargos extensively colocalized with the marker of the early endosomal compartment EEA1 in both cell bodies and dendrites. This endosome-associated protein was identified as a core component and actor of the homotypic endosome docking and fusion machinery (Simonsen et al., 1998; Christoforidis et al., 1999; Nielsen et al., 1999). In addition, we observed that (1) retrograde transport of receptor carrying vesicles occurred in dendrites, (2) $\mathrm{sst}_{2 \mathrm{~A}}$ receptor accumulated in a perinuclear compartment, and (3) depolymerization of microtubules resulted in accumulation of enlarged endosomes expressing both $\mathrm{sst}_{2 \mathrm{~A}}$ receptor and EEA1 at the periphery of cell bodies and within dendrites. According to these observations, the assembly of EEA1 on endosomes through a GTPhydrolyzing enzyme Rab5- and phosphatidylinositol-3phosphate-dependent mechanism has been proposed to recruit a minus-end-directed kinesin motor that moves early endosomes along microtubules toward the microtubuleorganizing center (Nielsen et al., 1999). Together, these results clearly demonstrate that $s^{2 \mathrm{~A}} \mathrm{c}$ cargoes are targeted to and retrogradely traffic through early endosomes expressing EEA1 in neuronal cells.

With time, however, colocalization of the receptor with EEA1 gradually disappeared. Interestingly, in contrast to the classical route taken by internalized GPCRs, sst $_{2 \mathrm{~A}}$ cargoes neither progress to the late endosomal compartment nor recycle back from the cell surface from early endosomes. Indeed, before recycling, sst ${ }_{2 \mathrm{~A}}$ receptors accumulate in a perinuclear compartment expressing trans-Golgi but not cis-Golgi or ER markers. Reaching the transGolgi compartment is not a consequence of the artificial expression system because we recently demonstrated that this phenomenon occurs when endogenous receptor are activated in vivo in the hippocampus (Csaba et al., 2007). Additional experiments are required to determine the molecular determinants and protein partners that drive the receptor to the TGN and the functional relevance of such a trafficking pathway. It remains also to be established whether other GPCR subtypes can recycle through the TGN after endocytosis, a phenomenon that has not been anticipated from studies in nonneuronal cells.

\section{References}

Ashby MC, Maier SR, Nishimune A, Henley JM (2006) Lateral diffusion drives constitutive exchange of AMPA receptors at dendritic spines and is regulated by spine morphology. J Neurosci 26:7046-7055.

Axelrod D, Koppel DE, Schlessinger J, Elson E, Webb WW (1976) Mobility measurement by analysis of fluorescence photobleaching recovery kinetics. Biophys J 16:1055-1069.

Bassant MH, Simon A, Poindessous-Jazat F, Csaba Z, Epelbaum J, Dournaud P (2005) Medial septal GABAergic neurons express the somatostatin sst2A receptor: functional consequences on unit firing and hippocampal theta. J Neurosci 25:2032-2041.

Blanpied TA, Scott DB, Ehlers MD (2002) Dynamics and regulation of clathrin coats at specialized endocytic zones of dendrites and spines. Neuron 36:435-449.

Bock JB, Lin RC, Scheller RH (1996) A new syntaxin family member implicated in targeting of intracellular transport vesicles. J Biol Chem 271:17961-17965.

Bock JB, Klumperman J, Davanger S, Scheller RH (1997) Syntaxin 6 functions in trans-Golgi network vesicle trafficking. Mol Biol Cell 8:1261-1271.

Christoforidis S, McBride HM, Burgoyne RD, Zerial M (1999) The Rab5 effector EEAl is a core component of endosome docking. Nature 397:621-625.

Csaba Z, Dournaud P (2001) Cellular biology of somatostatin receptors. Neuropeptides 35:1-23.

Csaba Z, Bernard V, Helboe L, Bluet-Pajot MT, Bloch B, Epelbaum J, Dournaud P (2001) In vivo internalization of the somatostatin sst2A receptor in rat brain: evidence for translocation of cell-surface receptors into the endosomal recycling pathway. Mol Cell Neurosci 17:646-661.

Csaba Z, Richichi C, Bernard V, Epelbaum J, Vezzani A, Dournaud P (2004) Plasticity of somatostatin and somatostatin sst2A receptors in the rat dentate gyrus during kindling epileptogenesis. Eur J Neurosci 19:2531-2538.

Csaba Z, Pirker S, Lelouvier B, Simon A, Videau C, Epelbaum J, Czech T, Baumgartner C, Sperk G, Dournaud P (2005) Somatostatin receptor type 2 undergoes plastic changes in the human epileptic dentate gyrus. J Neuropathol Exp Neurol 64:956-969.

Csaba Z, Lelouvier B, Viollet C, El Ghouzzi V, Toyama K, Videau C, Bernard V, Dournaud P (2007) Activated somatostatin type 2 receptors traffic in vivo in central neurons from dendrites to the trans Golgi before recycling. Traffic 8:820-834.

DeWire SM, Ahn S, Lefkowitz RJ, Shenoy SK (2007) Beta-arrestins and cell signaling. Annu Rev Physiol 69:483-510.

Dournaud P, Boudin H, Schonbrunn A, Tannenbaum GS, Beaudet A (1998) Interrelationships between somatostatin sst2A receptors and somatostatin-containing axons in rat brain: evidence for regulation of 
cell surface receptors by endogenous somatostatin. J Neurosci 18:1056-1071.

Dournaud P, Slama A, Beaudet A, Epelbaum J (2000) Somatostatin receptors. In: Handbook of chemical neuroanatomy, Vol 16, Peptide receptors, Pt I (Quirion R, Björklund A, Hökfelt T, eds), pp 1-43. Amsterdam: Elsevier Science.

Durocher Y, Perret S, Thibaudeau E, Gaumond MH, Kamen A, Stocco R, Abramovitz M (2000) A reporter gene assay for high-throughput screening of G-protein-coupled receptors stably or transiently expressed in HEK293 EBNA cells grown in suspension culture. Anal Biochem 284:316-326.

Ferguson SS (2001) Evolving concepts in G protein-coupled receptor endocytosis: the role in receptor desensitization and signaling. Pharmacol Rev 53:1-24.

Gainetdinov RR, Premont RT, Bohn LM, Lefkowitz RJ, Caron MG (2004) Desensitization of $\mathrm{G}$ protein-coupled receptors and neuronal functions. Annu Rev Neurosci 27:107-144.

Grady EF, Garland AM, Gamp PD, Lovett M, Payan DG, Bunnett NW (1995) Delineation of the endocytic pathway of substance P and its seven-transmembrane domain NK1 receptor. Mol Biol Cell 6:509-524.

Griffiths G, Hoflack B, Simons K, Mellman I, Kornfeld S (1988) The mannose 6-phosphate receptor and the biogenesis of lysosomes. Cell 52:329-341.

Gruenberg J, Maxfield FR (1995) Membrane transport in the endocytic pathway. Curr Opin Cell Biol 7:552-563.

Gupta A, Décaillot FM, Devi LA (2006) Targeting opioid receptor heterodimers: strategies for screening and drug development. AAPS J 8:E153-E159.

Hall RA, Premont RT, Chow CW, Blitzer JT, Pitcher JA, Claing A, Stoffel RH, Barak LS, Shenolikar S, Weinman EJ, Grinstein S, Lefkowitz RJ (1998) The beta2-adrenergic receptor interacts with the $\mathrm{Na}^{+} / \mathrm{H}^{+}$-exchanger regulatory factor to control $\mathrm{Na}^{+} / \mathrm{H}^{+}$exchange. Nature 392:626-630.

Kang J, Shi Y, Xiang B, Qu B, Su W, Zhu M, Zhang M, Bao G, Wang F, Zhang X, Yang R, Fan F, Chen X, Pei G, Ma L (2005) A nuclear function of beta-arrestin1 in GPCR signaling: regulation of histone acetylation and gene transcription. Cell 123:833-847.

Kassack MU, Hogger P, Gschwend DA, Kameyama K, Haga T, Graul RC, Sadee W (2000) Molecular modeling of G-protein coupled receptor kinase 2: docking and biochemical evaluation of inhibitors. AAPS PharmSci 2:1-13.

Mallard F, Tang BL, Galli T, Tenza D, Saint-Pol A, Yue X, Antony C, Hong W, Goud B, Johannes L (2002) Early/recycling endosomes-to-TGN transport involves two SNARE complexes and a Rab6 isoform. J Cell Biol 156:653-664.

Mastrodimou N, Lambrou GN, Thermos K (2005) Effect of somatostatin analogues on chemically induced ischaemia in the rat retina. Naunyn Schmiedebergs Arch Pharmacol 371:44-53.

Maxfield FR, McGraw TE (2004) Endocytic recycling. Nat Rev Mol Cell Biol 5:121-132.

McConalogue K, Dery O, Lovett M, Wong H, Walsh JH, Grady EF, Bunnett NW (1999) Substance P-induced trafficking of beta-arrestins. The role of beta-arrestins in endocytosis of the neurokinin-1 receptor. J Biol Chem 274:16257-16268.

Mukherjee S, Ghosh RN, Maxfield FR (1997) Endocytosis. Physiol Rev 77:759-803.

Nazarian R, Falcon-Perez JM, Dell'Angelica EC (2003) Biogenesis of lysosome-related organelles complex 3 (BLOC-3): a complex containing the Hermansky-Pudlak syndrome (HPS) proteins HPS1 and HPS4. Proc Natl Acad Sci USA 100:8770-8775.

Nelson CD, Perry SJ, Regier DS, Prescott SM, Topham MK, Lefkowitz RJ (2007) Targeting of diacylglycerol degradation to M1 muscarinic receptors by beta-arrestins. Science 315:663-666.

Nielsen E, Severin F, Backer JM, Hyman AA, Zerial M (1999) Rab5 regulates motility of early endosomes on microtubules. Nat Cell Biol 1:376-382.

Peineau S, Potier B, Petit F, Dournaud P, Epelbaum J, Gardette R (2003) AMPA-sst2 somatostatin receptor interaction in rat hypothalamus requires activation of NMDA and/or metabotropic glutamate receptors and depends on intracellular calcium. J Physiol (Lond) 546:101-117.

Perry SJ, Baillie GS, Kohout TA, McPhee I, Magiera MM, Ang KL, Miller WE,
McLean AJ, Conti M, Houslay MD, Lefkowitz RJ (2002) Targeting of cyclic AMP degradation to beta 2-adrenergic receptors by beta-arrestins. Science 298:834-836.

Pierce KL, Premont RT, Lefkowitz RJ (2002) Seven-transmembrane receptors. Nat Rev Mol Cell Biol 3:639-650.

Premont RT, Gainetdinov RR (2007) Physiological roles of G proteincoupled receptor kinases and arrestins. Annu Rev Physiol 69:511-534.

Pucadyil TJ, Chattopadhyay A (2007) The human serotonin1A receptor exhibits G-protein-dependent cell surface dynamics. Glycoconj J 24:25-31.

Puthenveedu MA, von Zastrow M (2006) Cargo regulates clathrin-coated pit dynamics. Cell 127:113-124.

Reits EA, Neefjes JJ (2001) From fixed to FRAP: measuring protein mobility and activity in living cells. Nat Cell Biol 3:E145-E147.

Robinson MS, Watts C, Zerial M (1996) Membrane dynamics in endocytosis. Cell 84:13-21.

Saito T, Iwata N, Tsubuki S, Takaki Y, Takano J, Huang SM, Suemoto T, Higuchi M, Saido TC (2005) Somatostatin regulates brain amyloid beta peptide Abeta42 through modulation of proteolytic degradation. Nat Med 11:434-439.

Santini F, Gaidarov I, Keen JH (2002) G protein-coupled receptor/arrestin3 modulation of the endocytic machinery. J Cell Biol 156:665-676.

Scherrer G, Tryoen-Toth P, Filliol D, Matifas A, Laustriat D, Cao YQ, Basbaum AI, Dierich A, Vonesh JL, Gaveriaux-Ruff C, Kieffer BL (2006) Knockin mice expressing fluorescent delta-opioid receptors uncover $\mathrm{G}$ protein-coupled receptor dynamics in vivo. Proc Natl Acad Sci USA 103:9691-9696.

Scott L, Zelenin S, Malmersjo S, Kowalewski JM, Markus EZ, Nairn AC, Greengard P, Brismar H, Aperia A (2006) Allosteric changes of the NMDA receptor trap diffusible dopamine 1 receptors in spines. Proc Natl Acad Sci USA 103:762-767.

Scott MG, Benmerah A, Muntaner O, Marullo S (2002) Recruitment of activated $\mathrm{G}$ protein-coupled receptors to pre-existing clathrin-coated pits in living cells. J Biol Chem 277:3552-3559.

Shenoy SK, Lefkowitz RJ (2005) Seven-transmembrane receptor signaling through beta-arrestin. Sci STKE 2005: $\mathrm{cm} 10$.

Simonsen A, Lippe R, Christoforidis S, Gaullier JM, Brech A, Callaghan J, Toh BH, Murphy C, Zerial M, Stenmark H (1998) EEA1 links PI(3)K function to Rab5 regulation of endosome fusion. Nature 394:494-498.

Stumm RK, Zhou C, Schulz S, Endres M, Kronenberg G, Allen JP, Tulipano G, Hollt V (2004) Somatostatin receptor 2 is activated in cortical neurons and contributes to neurodegeneration after focal ischemia. J Neurosci 24:11404-11415.

Tsao P, von Zastrow M (2000) Downregulation of G protein-coupled receptors. Curr Opin Neurobiol 10:365-369.

Tsao P, Cao T, von Zastrow M (2001) Role of endocytosis in mediating downregulation of G-protein-coupled receptors. Trends Pharmacol Sci 22:91-96.

Tulipano G, Stumm R, Pfeiffer M, Kreienkamp HJ, Hollt V, Schulz S (2004) Differential beta-arrestin trafficking and endosomal sorting of somatostatin receptor subtypes. J Biol Chem 279:21374-21382.

Vezzani A, Hoyer D (1999) Brain somatostatin: a candidate inhibitory role in seizures and epileptogenesis. Eur J Neurosci 11:3767-3776.

Wolfe BL, Trejo J (2007) Clathrin-dependent mechanisms of G proteincoupled receptor endocytosis. Traffic 8:462-470.

Woodman PG (2000) Biogenesis of the sorting endosome: the role of Rab5. Traffic 1:695-701.

Yudowski GA, Puthenveedu MA, von Zastrow M (2006) Distinct modes of regulated receptor insertion to the somatodendritic plasma membrane. Nat Neurosci 9:622-627.

Zerial M, McBride H (2001) Rab proteins as membrane organizers. Nat Rev Mol Cell Biol 2:107-117.

Zitzer H, Richter D, Kreienkamp HJ (1999a) Agonist-dependent interaction of the rat somatostatin receptor subtype 2 with cortactin-binding protein 1. J Biol Chem 274:18153-18156.

Zitzer H, Honck HH, Bachner D, Richter D, Kreienkamp HJ (1999b) Somatostatin receptor interacting protein defines a novel family of multidomain proteins present in human and rodent brain. J Biol Chem 274: 32997-33001. 